\title{
Neoproterozoic glacial deposits from the Araçuaí orogen, Brazil: Age, provenance and correlations with the São Francisco craton and West Congo belt
}

\author{
M. Babinski ${ }^{\text {a, } *, 1}$, A.C. Pedrosa-Soares ${ }^{\text {b, }}{ }^{\text {, R.I.F. Trindade }}{ }^{\mathrm{c}, 1}$, M. Martins $^{\mathrm{b}}$, C.M. Noce ${ }^{\mathrm{b}, 1}$, D. Liu ${ }^{\mathrm{d}}$ \\ a Instituto de Geociências, Universidade de São Paulo, Rua do Lago, 562, CEP 05580-080, São Paulo, SP, Brazil \\ b Universidade Federal de Minas Gerais, CPMTC-IGC, CEP 31270-901, Belo Horizonte, MG, Brazil \\ ' Instituto de Astronomia, Geofísica e Ciências Atmosféricas, Universidade de São Paulo, Rua do Matão, 1226, CEP 05508-090, São Paulo, SP, Brazil \\ d Beijing SHRIMP Centre, Chinese Academy of Geological Sciences, 26 Baiwanzhuang Road, Beijing 100037, China
}

\section{A R T I C L E I N F O}

\section{Article history:}

Received 23 November 2010

Received in revised form 15 March 2011

Accepted 5 April 2011

Available online 6 May 2011

\section{Keywords:}

$\mathrm{U}-\mathrm{Pb}$ SHRIMP geochronology

Neoproterozoic glaciations

Macaúbas Group

Brazil

Araçuaí-West Congo orogen

\begin{abstract}
A B S T R A C T
Glacigenic diamictite successions of the Macaúbas Group are widespread in the western domain of the Araçuaí orogen, east of the São Francisco craton (Brazil). Diamictites also occur on this craton and in the African counterpart of the Araçuaí orogen, the West Congo belt. Detrital zircon grains from the matrix of diamictites and sandstones from the Macaúbas Group were dated by the U-Pb SHRIMP technique. The geochronological study sets the maximum depositional age of the glacial diamictites at $900 \mathrm{Ma}$, and indicates multiple sources for the Macaúbas basin with ages ranging from 900 to 2800 Ma. Sm-Nd $\mathrm{T}_{\mathrm{DM}}$ model ages, determined on whole rock samples, range from $1.8 \mathrm{Ga}$ to $2.5 \mathrm{Ga}$ and get older up-section. Comparison of our data with those from the cratonic area suggest that these glacial deposits can be correlated to the Jequitaí and Carrancas diamictites in the São Francisco craton, and to the Lower Mixtite Formation of the West Congolian Group, exposed in Africa. The 900-1000 Ma source is most probably represented by the Zadinian-Mayumbian volcanic rocks and related granites from the West Congo belt. However, one of the most voluminous sources, with ages in the 1.1-1.3 Ga interval, has not been detected in the São Francisco-Congo craton. Possible sources for these grains could occur elsewhere in Africa, or possibly from within the Brasília Belt in western central Brazil.
\end{abstract}

(C) 2011 International Association for Gondwana Research. Published by Elsevier B.V. All rights reserved.

\section{Introduction}

Neoproterozoic glacial deposits are found in almost all continental shields (Chumakov and Elston, 1989), thus leading some authors to propose episodes of a panglacial world (Hoffman, 2009). But the existence of such extreme glacial scenarios still requires a better knowledge of the depositional age and provenance of glacigenic deposits which are mostly represented by diamictites.

In Brazil, diamictites are remarkably abundant in the western domain of the Araçuaí orogen, located to the east of the São Francisco craton (Fig. 1). They belong to the Macaúbas Group (Fig. 2), a thick volcano-sedimentary succession that represents a precursor basin of the Araçuaí orogen, and includes pre-glacial fluvial to marine sediments, mostly glacio-marine diamictites with minor rift-related volcanic rocks, and post-glacial passive margin sediments and oceanic deposits (Karfunkel and Hoppe, 1988; Pedrosa-Soares et al., 1992,

\footnotetext{
* Corresponding author.

E-mail addresses: babinski@usp.br (M. Babinski), pedrosa@igc.ufmg.br (A.C. Pedrosa-Soares), rtrindad@iag.usp.br (R.I.F. Trindade), maximilianomartins@yahoo.com.br (M. Martins), noce@igc.ufmg.br (C.M. Noce), liudunyi@beijing.shrimp.cn (D. Liu).

${ }^{1}$ Research fellow of the Brazilian Scientific Council (CNPq).
}

2001, 2008; Uhlein et al., 1999). In its original definition (e.g., Moraes and Guimarães, 1931), the name Macaúbas should be exclusively applied to refer to the extensive unit with diamictite formations that underwent regional deformation and metamorphism within the Araçuaí orogen. But diamictites also occur in relatively small areas on the São Francisco craton (Fig. 1), where the best evidence of glaciation has been reported from the Jequitaí and Bebedouro Formations. These include striated and grooved pavements, glacioterrestrial sediments, faceted and striated flat-iron-shaped cobbles and pebbles, dropstones, and esker-like bodies (e.g., Figueiredo et al., 2009; Gravenor and Monteiro, 1983; Hettich and Karfunkel, 1978; Isotta et al., 1969; Karfunkel et al., 2002; Karfunkel and Hoppe 1988; Martins-Neto et al., 1999, 2001; Martins-Neto and Hercos, 2002; Montes et al., 1985; Rocha-Campos and Hasui 1981; Uhlein et al., 1999; Viveiros and Walde 1976). The Carrancas diamictite occurs in only a few outcrops and boreholes where it is covered by the Sete Lagoas Formation (Kuchenbecker et al., 2010; Schöll, 1972; Tuller, 2009). This diamictite forms the lowermost unit of the pelitecarbonate cratonic cover (Bambuí Group), which includes a cap carbonate dated at $740 \pm 22 \mathrm{Ma}$ (Babinski et al., 2007).

The stratigraphic correlation of the Macaúbas deposits with the glacial units found in the São Francisco craton is masked by the structural complexity of the Araçuaí belt. The Macaúbas Group was thrust over the pelite-carbonate cover of the São Francisco craton and 

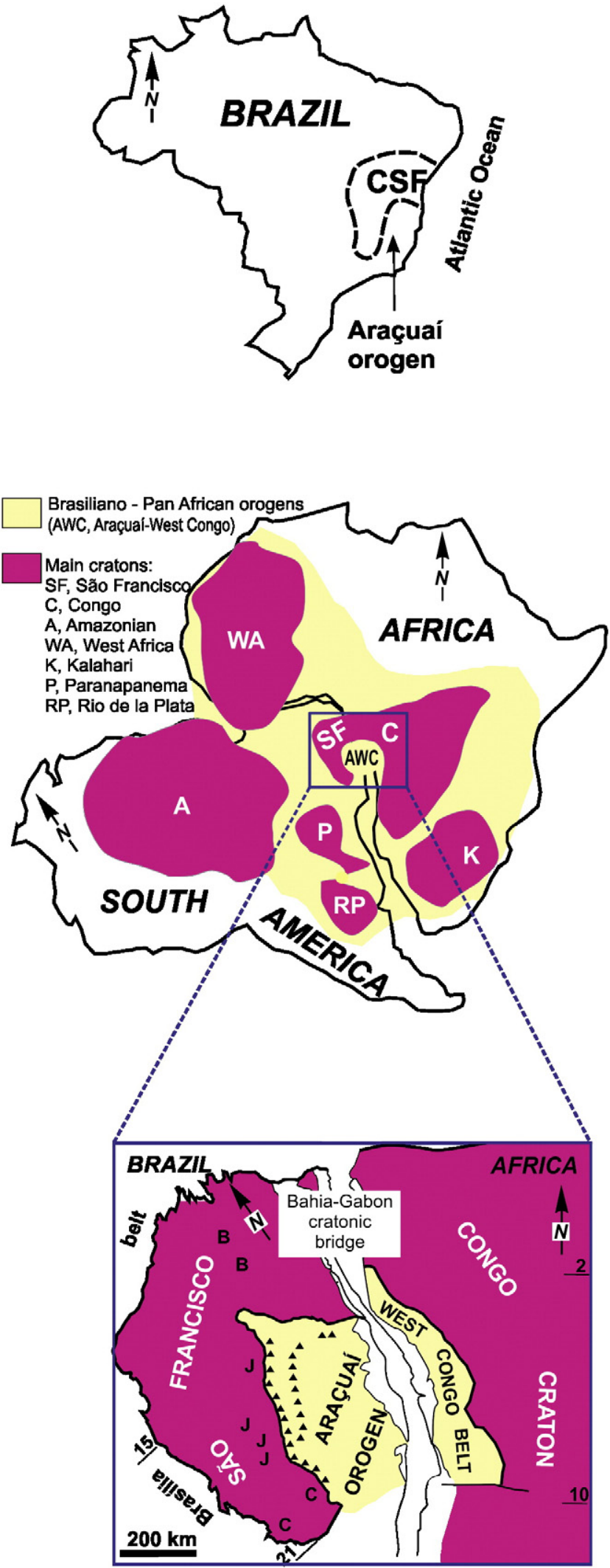

Location of the exposure region of Macaúbas diamictites in the Araçuaí orogen

Fig. 1. Location of the Araçuaí orogen in Brazil (CSF, São Francisco craton) and in Western Gondwana together with its African counterpart, the West Congo belt. The exposure region of Macaúbas diamictites (triangles) is shown in the palaeotectonic fit of the Araçuaí-West Congo orogen and related São Francisco-Congo craton. B, C and J indicate locations of Bebedouro, Carrancas and Jequitaí diamictites on the São Francisco craton. does not show any direct field relation with the Jequitaí and Carrancas diamictites (Figs. 1 and 3). The same complexities also appear when trying to correlate these units with diamictites found in the West Congo belt (Fig. 1), the counterpart of the Araçuaí orogen located in central west Africa (Pedrosa-Soares et al., 2008; Trompette, 1994).

The age and provenance of these diamictites in both continents is still poorly constrained. In a regional scale, these data would allow a more refined correlation between the diamictite successions of the Araçuaí orogen, São Francisco craton and West Congo belt. In global scale, it would enable the correlation to the Neoproterozoic glacial events of one of the largest and thickest diamictite successions of this period (e.g. Hoffman and Li, 2009). Here we present new U-Pb SHRIMP ages obtained on detrital zircon grains recovered from pre-glacial sandstones and glacigenic diamictites of the Macaúbas Group. In addition, an attempt to date mafic volcanics interlayered with diamictites of the Macaúbas Group was done. The aims of our work are (i) defining the maximum depositional age of glacial rocks and tentatively correlate them to the global Neoproterozoic glacial periods/events (e.g. Kaigas, Sturtian, Marinoan, and Gaskiers); and (ii) obtain information about the provenance of sediments deposited in the Macaúbas basin.

\section{Geotectonic setting}

The Araçuaí-West Congo orogen comprises the Neoproterozoic orogenic domains located to the southeast of the São Francisco craton in Brazil, and to the southwest of the Congo craton in Africa (Fig. 1). Prior to the opening of the South Atlantic Ocean, the São Francisco and Congo cratons were connected by means of a continental bridge, the BahiaGabon cratonic bridge (Alkmim et al., 2006; Cordani et al., 2003; Pedrosa-Soares et al., 2001, 2008; Porada, 1989; Trompette, 1994). Considering that the youngest orogenic event in the cratonic bridge occurred around $2.0 \mathrm{Ga}$, the continental link between the São Francisco and Congo cratons must have been formed during the Palaeoproterozoic and remained until the onset of the Atlantic opening. To the south of the Bahia-Gabon cratonic bridge, the Araçuaí-West Congo orogen evolved inside an embayment (an inland-sea basin partially floored by oceanic crust) into the São Francisco-Congo palaeocontinent. The evolution of this confined orogen lasted from the opening of the precursor basin at the beginning of the Neoproterozoic until late orogenic processes near the Cambrian-Ordovician boundary (Alkmim et al., 2006; PedrosaSoares et al., 2001, 2008).

During the Cretaceous opening of the South Atlantic Ocean, the Araçuaí-West Congo orogen was split up into two quite different but complementary counterparts: the Araçuaí orogen and the West Congo belt (Pedrosa-Soares et al., 2008). However, both counterparts inherited diamictite successions that together with the confined nature of the precursor basin system suggest a similar paleoenvironmental evolution.

\subsection{Regional geology}

The Macaúbas Group represents a very extensive and thick volcanosedimentary pile (probably thicker than $12 \mathrm{~km}$; Uhlein et al., 1999) that filled in the precursor basin of the Araçuaí orogen (Fig. 2). Proximal units of the Macaúbas Group and late Tonian anorogenic intrusions record the continental rift stage of the Macaúbas basin (Pedrosa-Soares et al., 2001, 2008; Silva et al., 2008). In the southern part of this basin (south of latitude $17^{\circ} \mathrm{S}$ ), the rift evolved into a narrow oceanic basin, represented by the distal Macaúbas Group and associated mafic-ultramafic ophiolite slivers (Pedrosa-Soares et al., 1992, 2001, 2008; Queiroga et al., 2007).

Based on the occurrence of glacigenic diamictites, the Macaúbas Group is subdivided, from base to top and west to east (Figs. 2 and 3), into a pre-glacial diamictite-free succession (Matão, Duas Barras and Rio Peixe Bravo formations), a glacigenic succession (Serra do Catuni, Nova Aurora and Lower Chapada Acauã formations), and a post-glacial succession (Upper Chapada Acauã and Ribeirão da Folha formations). 


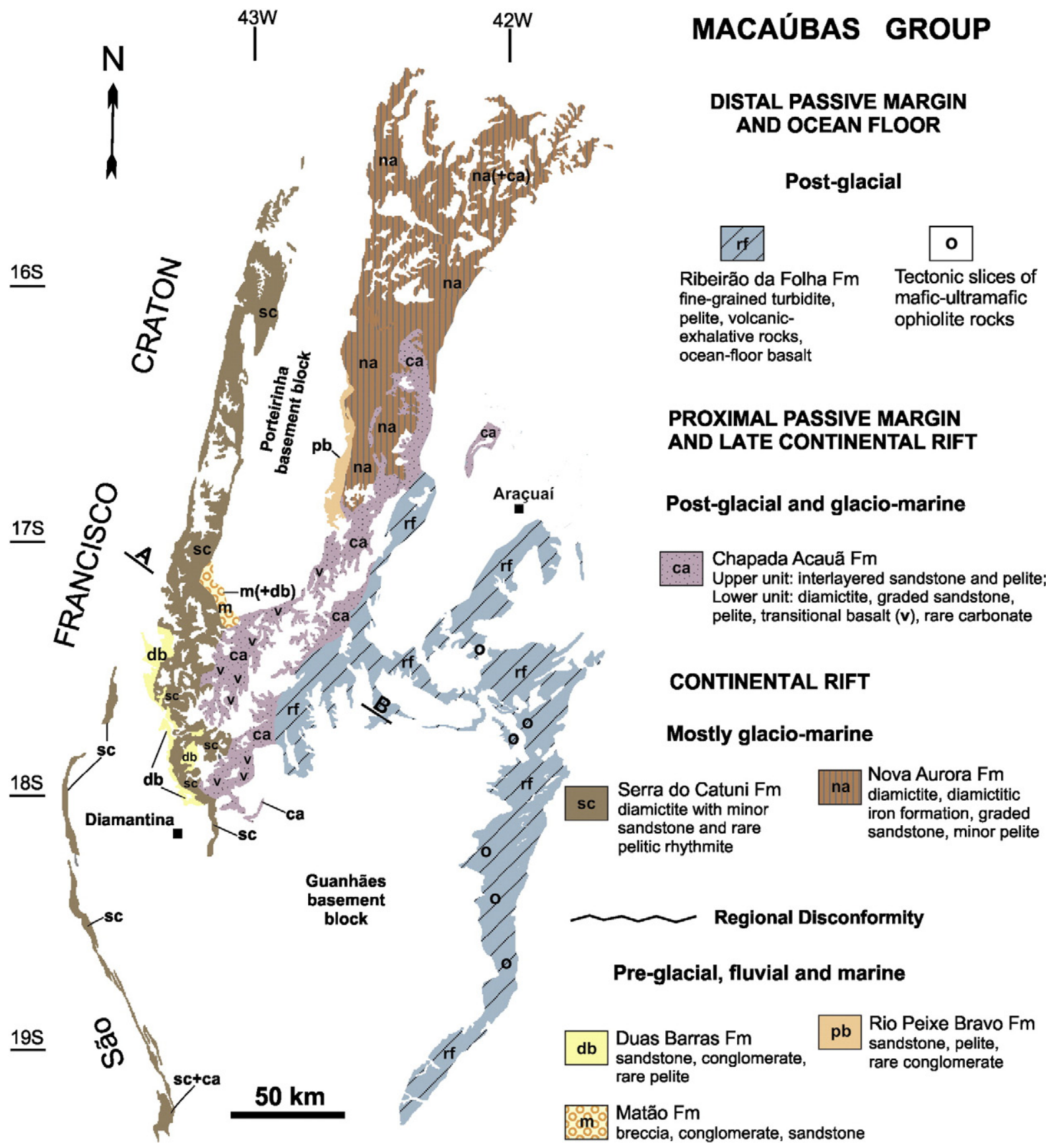

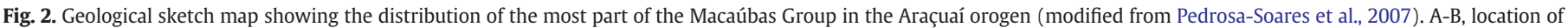
section shown in Fig. 3.

The basal deposits of the Macaúbas Group are represented by the Matão, Duas Barras and Rio Peixe Bravo formations (Fig. 2). The Matão Formation consists of breccia and conglomerate, rich in sandstone pebbles and cobbles, covered by sandstone with conglomeratic lenses. Erosive unconformity and normal faults outline the contact between the basement (locally represented by eolian sandstone of the Espinhaço Supergroup) and the Matão Formation, which records sedimentation under unstable tectonic conditions related to the early rift stage of the Macaúbas basin and contains detrital zircons with ages ranging from $1.16 \mathrm{Ga}$ to $2.80 \mathrm{Ga}$ (Martins, 2006; Martins et al., 2008). The youngest detrital zircon dated at 1.16 Ga defines the maximum depositional age of this formation (Martins et al., 2008). The Duas Barras Formation consists of sandstone and conglomeratic sandstone with variable contents of mica, feldspar, iron oxide and/or lithic fragments, quartz sandstone, conglomerate and rare pelite. It shows fluvial and shallow marine sedimentary facies and bimodal (NW-SE and SE-NW) paleocurrent sets (Grossi-Sad et al., 1997; Martins, 2006; Martins et al., 2008; Noce, 1997). The Rio Peixe Bravo Formation consists of micaceous, ferruginous and/or feldspathic sandstone, pelite locally rich in hematite and/or graphite, and rare clast-supported conglomerate (Grossi-Sad et al., 1997; Viveiros et al., 1979). These three units show no evidence of glaciation and represent fluvial to marine sedimentation during the continental rift stage of the Macaúbas basin (Martins et al., 2008; Noce et al., 1997; Pedrosa-Soares et al., 2008).

A regional disconformity occurs between the diamictite-free Duas Barras Formation and the overlying Serra do Catuni Formation, the most proximal glacigenic unit of the Macaúbas Group (Karfunkel and Hoppe, 1988; Uhlein et al., 1999). Locally, the Serra do Catuni diamictite shows 


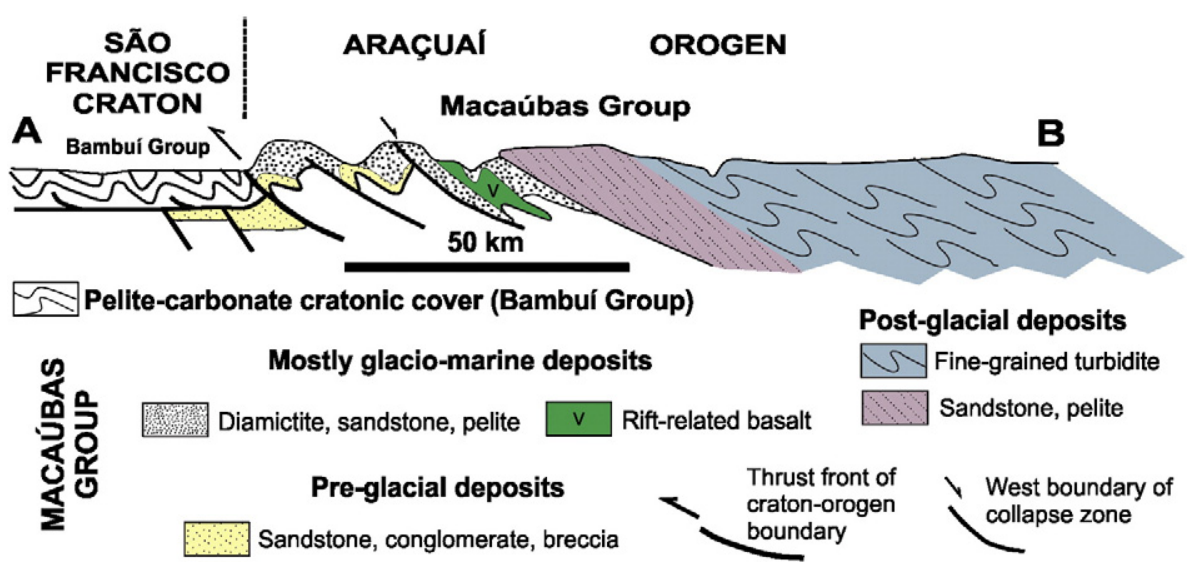

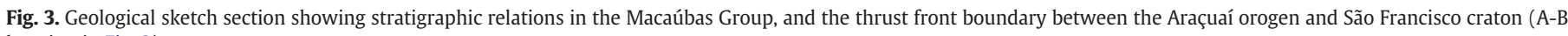
location in Fig. 2).

an erosional channelized contact with the Duas Barras Formation, but normal and tectonic contacts are also observed (Grossi-Sad et al., 1997; Noce, 1997).

The Serra do Catuni Formation is a very extensive and homogeneous unit that persistently occurs for more than $400 \mathrm{~km}$ in the N-S direction, along the western border of the Araçuaí orogen (Fig. 2). This formation is very rich in massive diamictite with a poorly sorted, muddy-sandstone matrix composed of detrital quartz, K-feldspar and carbonate. The metamorphic foliation is marked mainly by fine-grained muscovite and stretched quartz. The clasts, ranging in size from granules to boulders, are also poorly sorted in texture and composition (milky quartz, sandstone, granitoid, carbonate and mafic rock). Faceted and striated flat-iron-shaped cobbles and pebbles can also be found in the Serra do Catuni diamictite. Lenses of massive sandstone up to $2 \mathrm{~m}$ thick appear mainly in the upper part of the diamictite pile. This sandstone is poorly sorted and consists of quartz with minor K-feldspar, carbonate and iron oxides (Grossi-Sad et al., 1997; Martins, 2006).

The Nova Aurora Formation overlies the pre-glacial Rio Peixe Bravo Formation and is a distal correlative of the Serra do Catuni Formation (Fig. 2). This unit comprises diamictite and thick layers of diamictitic iron formation, with minor graded sandstone and rare pelite (Grossi-Sad et al. 1997; Pedrosa-Soares and Oliveira, 1997; Uhlein et al., 1999; Vilela, 2010; Viveiros et al. 1979).

The Chapada Acauã Formation includes a lower diamictite unit and an upper diamictite-free unit (Fig. 2). The Lower Chapada Acauã Formation consists of stratified diamicite, graded sandstone, pelite and mafic volcanic rocks (Gradim et al., 2005; Grossi-Sad et al., 1997; PedrosaSoares et al., 1992). A few carbonate lenses occur at the top of this formation (Grossi-Sad et al., 1997; Pedrosa-Soares and Oliveira, 1997). The mafic volcanic rocks, metamorphosed to greenschists, show pillow structures and other features of subaquatic flows (Gradim et al., 2005; Schrank et al., 1978; Uhlein et al., 1998). They have tholeiitic basalt protoliths with a dominant within-plate geochemical signature (Gradim et al., 2005), Sm-Nd T $\mathrm{DM}_{\mathrm{DM}}$ model ages of $c .1 .5 \mathrm{Ga}$, and contain detrital and xenocrystic zircons with ages ranging from Archean to Mesoproterozoic (Babinski et al., 2005). The youngest dated zircon sets the maximum age of the volcanism at $1.16 \mathrm{Ga}$. It is interpreted as a transitional mafic magma that migrated through thinned continental crust in an extensional marine basin during the transitional phase from late rift to the early passive margin of the Macaúbas basin (Pedrosa-Soares et al., 2008).

The Lower Chapada Acauã Formation gradually passes upwards to the diamictite-free package of the Upper Chapada Acauã Formation, which is formed by a sandstone-pelite succession (Fig. 2). It is interpreted as a post-glacial unit deposited in a shelf environment during the passive margin stage of the Macaúbas basin (Grossi-Sad et al., 1997; Martins-Neto et al., 2001 and Noce et al., 1997; Pedrosa-Soares and Oliveira, 1997). To the east, this unit gives way to the fine-grained turbidites of the Ribeirão da Folha Formation (Pedrosa-Soares et al., 1992, 2008). The Ribeirão da Folha Formation is a diamictite-free unit and includes distal passive margin and ocean floor deposits (Fig. 2). The age of deposition of these sediments is constrained by the $\mathrm{U}-\mathrm{Pb}$ age of $660 \pm 29 \mathrm{Ma}$, obtained from euhedral crystals within a meta-plagiogranite associated with meta-mafic rocks, and interpreted as the time of magmatic crystallization of an ophiolite sliver (Queiroga et al., 2007).

The whole Macaúbas Group was affected by Ediacaran-Cambrian orogensis and the oldest ages of c. $580 \mathrm{Ma}$ from syn-collisional metamorphic-anatectic rocks set the upper limit of sedimentation for the succession (Pedrosa-Soares et al., 2008 and references therein).

\section{Analytical procedures}

Sm and Nd isotopic analyses were carried out at the Geochronological Research Center of the São Paulo University. Whole rock samples were powdered and dissolved in $\mathrm{HF}, \mathrm{HNO}_{3}$, and $\mathrm{HCl}$ media. Separation and purification of Sm and $\mathrm{Nd}$ were carried out by standard ion exchange procedures using RE and LN Eichron resins. Sm and Nd isotope data were obtained on a multi-collector MAT262 mass spectrometer. The measured ${ }^{143} \mathrm{Nd} /{ }^{144} \mathrm{Nd}$ ratios were normalized to 0.7219 . The ${ }^{143} \mathrm{Nd} /{ }^{144} \mathrm{Nd}$ ratios of La Jolla and BCR-1, measured in the laboratory, are $0.511849 \pm 0.000025(1 \sigma)$ and $0.512662 \pm 0.000027$ $(1 \sigma)$, respectively. Total blanks for Sm and Nd are 100 and $120 \mathrm{pg}$, respectively. The $\mathrm{Sm}-\mathrm{Nd}$ model ages reported here are based on a depleted mantle model (DePaolo, 1981) and are interpreted as mean crustal residence ages.

Zircon grains were separated using standard heavy liquid and magnetic techniques at the Geochronological Research Center, University of São Paulo. The U-Pb analyses were carried out on the SHRIMP II ion microprobe at the Beijing SHRIMP Centre, Institute of Geology, Chinese Academy of Geological Sciences. Grains were mounted in an epoxy disk with the Temora zircon standard (417 Ma; Black et al., 2003) and polished to expose their centers. Internal structures of zircon grains were revealed by cathodoluminescence $(\mathrm{CL})$ images obtained at the Institute of Mineral Resources, Chinese Academy of Geological Sciences. The analytical procedures were similar to those described by Williams (1998). Four or five scans through the mass stations were made for each age determination. U abundance was calibrated using the standard SL13 ( $\mathrm{U}=238 \mathrm{ppm}$, Williams, 1998) and ${ }^{206} \mathrm{~Pb} /{ }^{238} \mathrm{U}$ ratio was calibrated using the standard Temora $\left({ }^{206} \mathrm{~Pb} /{ }^{238} \mathrm{U}\right.$ age $=417 \mathrm{Ma}$; Black et al., 2003). Decay constants used for age calculation are those recommended by Steiger and Jäger (1977). Measured ${ }^{204} \mathrm{~Pb}$ was applied for the common lead correction, and data processing was carried out using the Squid and Isoplot programs (Ludwig, 2001). The uncertainties for the measured ratios are given at the one sigma level. All obtained data were plotted on the concordia diagram, but only zircon ages more concordant 
Table 1

$\mathrm{Sm}-\mathrm{Nd}$ isotopic data from whole-rock samples from the Macaúbas Group.

\begin{tabular}{|c|c|c|c|c|c|c|c|c|c|c|}
\hline $\begin{array}{l}\text { Sample } \\
\text { ID }\end{array}$ & Rock & Geological unit & $\begin{array}{l}\text { Sm } \\
(\mathrm{ppm})\end{array}$ & $\begin{array}{l}\mathrm{Nd} \\
(\mathrm{ppm})\end{array}$ & $\begin{array}{l}{ }^{147} \mathrm{Sm} / \\
{ }^{144} \mathrm{Nd}\end{array}$ & Error & $\begin{array}{l}{ }^{143} \mathrm{Nd} / \\
{ }^{144} \mathrm{Nd}\end{array}$ & $\begin{array}{l}\text { Error } \\
2 \sigma\end{array}$ & $\begin{array}{l}\text { Age } T_{\mathrm{DM}} \\
\text { (Ga) }\end{array}$ & $\varepsilon_{(0)}$ \\
\hline MG05-04 & Sandstone & Duas Barras & 0.710 & 4.219 & 0.1017 & 0.0006 & 0.511645 & 0.000010 & 1.9 & -19.4 \\
\hline MG08-06 & Quartz-sandstone & Duas Barras & 0.878 & 5.550 & 0.0956 & 0.0006 & 0.511618 & 0.000009 & 1.8 & -19.9 \\
\hline MG05-01 & Diamictite & Serra do Catuni & 2.281 & 11.915 & 0.1158 & 0.0004 & 0.511599 & 0.000009 & 2.3 & -20.3 \\
\hline MG05-02 & Diamictite & Serra do Catuni & 2.140 & 10.963 & 0.1181 & 0.0004 & 0.511613 & 0.000008 & 2.3 & -20.0 \\
\hline MG08-09 & Diamictite & Chapada Acauã Inf. & 2.904 & 15.970 & 0.1100 & 0.0007 & 0.511531 & 0.000011 & 2.2 & -21.6 \\
\hline MG08-11 & Mica-rich wacke & Chapada Acauã Inf. & 1.544 & 8.204 & 0.1138 & 0.0007 & 0.511573 & 0.000007 & 2.3 & -20.8 \\
\hline MG08-12 & Wacke & Chapada Acauã Sup. & 2.022 & 10.772 & 0.1135 & 0.0007 & 0.511383 & 0.000008 & 2.5 & -24.5 \\
\hline MG05-03 & Basalt & Chapada Acauã Inf. & 3.411 & 13.906 & 0.1483 & 0.0005 & 0.512302 & 0.000012 & 1.7 & -6.6 \\
\hline MG05-23 & Clast of basalt & Chapada Acauã Inf. & 4.778 & 19.413 & 0.1488 & 0.0005 & 0.512329 & 0.000010 & 1.7 & -6.0 \\
\hline $\mathrm{R} 5.2^{\mathrm{a}}$ & Basalt & Chapada Acauã Inf. & 1.119 & 4.751 & 0.1424 & 0.0005 & 0.512330 & 0.000009 & 1.5 & -6.0 \\
\hline
\end{tabular}

a Data from Babinski et al., 2005.

than $85 \%$ were used in the histogram plots. Since all $\mathrm{U}-\mathrm{Pb}$ ages are older than $800 \mathrm{Ma}$, they are all mentioned as ${ }^{207} \mathrm{~Pb} /{ }^{206} \mathrm{~Pb}$ ages, unless referred otherwise, in order to avoid misunderstanding related to discordant ages.

\section{Results}

\subsection{Sm-Nd data}

Sm-Nd isotopic data were obtained on samples for all units of the Macaúbas Group, except the Matão Formation (Table 1, Fig. 4). Sandstones of the pre-glacial units show $\mathrm{T}_{\mathrm{DM}}$ ages of $1.8-1.9 \mathrm{Ga}$, and the diamictites and sandstones from the Serra do Catuni and Lower Chapada Acauã Formations yield older $\mathrm{T}_{\mathrm{DM}}$ ages of $2.2 \mathrm{Ga}$ to $2.3 \mathrm{Ga}$; all samples show very negative $(-20$ to -24$)$ epsilon $_{\mathrm{Nd}(0)}$ values, consistent with the predominance of Palaeoproterozoic rocks as the source of the sediments. These results suggest that similar source areas supplied sediments for the whole diamictite pile, but younger sediments could have predominated in the lowermost non-glacial units thus lowering slightly their $\mathrm{T}_{\mathrm{DM}}$ model ages. In contrast, the $\mathrm{T}_{\mathrm{DM}}$ ages determined on mafic volcanics with tholeiitic affinity from the Lower Chapada Acauã Formation are between $1.7 \mathrm{Ga}$ and $1.5 \mathrm{Ga}$, and have less negative $(-6)$ epsilon $_{\mathrm{Nd}(0)}$ values. These data are in agreement with those previously obtained by Babinski et al. (2005) and reinforce the idea that the mafic magma was contaminated by the thinned continental crust of the Macaúbas rift system during its ascent.

\subsection{U-Pb SHRIMP data}

Zircon grains separated from four clastic sedimentary rocks and from a mafic volcanic rock were dated. Given that our main objective was to determine the maximum depositional age of glacial deposits, we selected for analyses: (i) the sandstones of the Duas Barras and Rio Peixe Bravo Formations, two of the lowermost units of the Macaúbas Group, (ii) the overlying glacial diamictites of the Serra do Catuni Formation, and (iii) a mafic volcanic rock with pillow structures from the Lower Chapada Acauã Formation (Fig. 2).

\subsubsection{Sandstone from the Duas Barras Formation (MG05-04)}

The detrital zircons separated from this quartzite are normally elongated and rounded, and show oscillatory zoning on the CL images (Fig. 5). Their sizes range from 80 to $300 \mu \mathrm{m}$. The 23 detrital zircon grains separated from this sandstone yielded $\mathrm{U}-\mathrm{Pb}$ ages ranging from 2550 to $900 \mathrm{Ma}$ (Table 2; Fig. 6), but most of them fall into two age intervals of 1.0 to $1.25 \mathrm{Ga}$ ( $40 \%$ of the population), and 1.8 to $2.1 \mathrm{Ga}$ ( $40 \%$ of the population), suggesting that those were the ages of the most important sources of the sediments (Fig. 7). The youngest zircon showed a ${ }^{238} \mathrm{U} /{ }^{206} \mathrm{~Pb}$ age of $900 \pm 21 \mathrm{Ma}$ which is considered the maximum depositional age of the pre-glacial sandstones from the Duas Barras Formation.

\subsubsection{Sandstone from the Rio Peixe Bravo Formation (OPU 2654)}

Most zircon grains separated from this sample are subheudral to rounded, and are less than $200 \mu \mathrm{m}$ long. The CL images show oscillatory zoning in most of the grains; few zircons have homogeneous internal structures (Fig. 5). Eighteen grains were analyzed from this sandstone and fourteen grains cluster at ca. 2.1 Ga yielding a ${ }^{207} \mathrm{~Pb} /{ }^{206} \mathrm{~Pb}$ mean age of $2097 \pm 44 \mathrm{Ma}$; 3 grains have younger ages and one grain gave an older age (Table 3, Fig. 6). In the frequency histogram the 2.1 Ga peak is prominent (Fig. 7), and the distribution of ages found in these distal deposits contrasts with that observed in the more proximal units. The

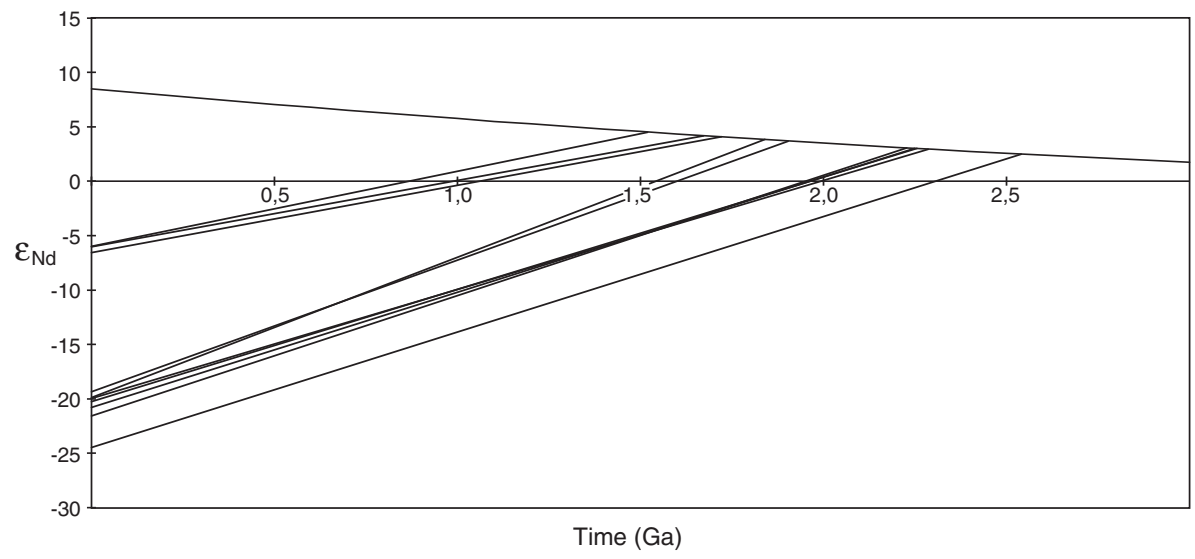

Fig. 4. Nd evolution diagram for different lithostratiraphic units of the Macaúbas Group. 


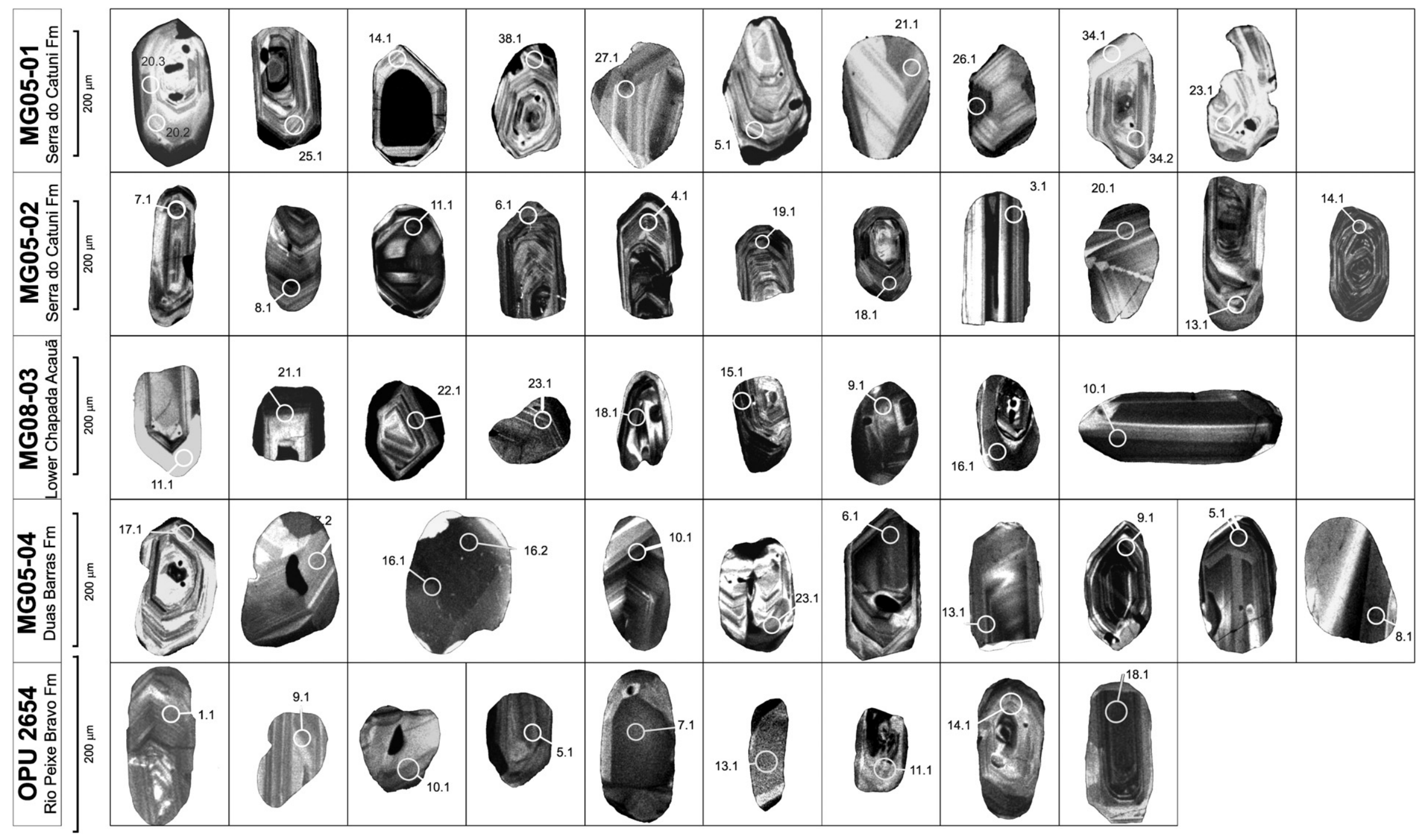

Fig. 5. Cathodoluminescence images of analyzed detrital zircon crystals. 
Table 2

U-Pb SHRIMP data from detrital zircons of sample MG05-04 (Duas Barras Formation).

\begin{tabular}{|c|c|c|c|c|c|c|c|c|c|c|c|c|c|c|c|c|c|}
\hline \multirow{2}{*}{$\begin{array}{l}\text { Grain. } \\
\text { spot }\end{array}$} & \multirow{2}{*}{$\begin{array}{l}\mathrm{U} \\
(\mathrm{ppm})\end{array}$} & \multirow{2}{*}{$\begin{array}{l}\text { Th } \\
(\mathrm{ppm})\end{array}$} & \multirow{2}{*}{$\begin{array}{l}{ }^{232} \mathrm{Th} / \\
{ }^{238} \mathrm{U}\end{array}$} & \multirow{2}{*}{$\begin{array}{l}{ }^{206} \mathrm{~Pb}^{*} \\
(\mathrm{ppm})\end{array}$} & \multirow[t]{2}{*}{${ }^{206} \mathrm{Pbc} \%$} & \multicolumn{6}{|c|}{ Radiogenic ratios } & \multicolumn{5}{|c|}{ Age (Ma) } & \multirow[b]{2}{*}{ \% Disc. } \\
\hline & & & & & & ${ }^{206} \mathrm{~Pb} /{ }^{238} \mathrm{U}$ & $\pm \%$ & ${ }^{207} \mathrm{~Pb} /{ }^{235} \mathrm{U}$ & $\pm \%$ & ${ }^{207} \mathrm{~Pb} /{ }^{206} \mathrm{~Pb}$ & \pm & $\rho$ & ${ }^{206} \mathrm{~Pb} /{ }^{238} \mathrm{U}$ & \pm & ${ }^{207} \mathrm{~Pb} /{ }^{206} \mathrm{~Pb}$ & \pm & \\
\hline 1.1 & 215 & 193 & 0.93 & 71.4 & 0.09 & 0.385 & 2.10 & 6.58 & 2.2 & 0.1239 & 0.76 & 0.938 & 2101 & 37 & 2013 & 14 & -4 \\
\hline 2.1 & 190 & 152 & 0.83 & 50.5 & 0.47 & 0.309 & 2.10 & 5.68 & 2.6 & 0.1336 & 1.62 & 0.790 & 1733 & 32 & 2146 & 28 & 19 \\
\hline 3.1 & 245 & 260 & 1.10 & 75.1 & 0.08 & 0.356 & 2.10 & 5.61 & 2.2 & 0.1142 & 0.81 & 0.931 & 1964 & 35 & 1867 & 15 & -5 \\
\hline 4.1 & 102 & 55 & 0.55 & 34.2 & 0.21 & 0.387 & 2.20 & 6.67 & 2.5 & 0.1250 & 1.21 & 0.873 & 2110 & 39 & 2029 & 21 & -4 \\
\hline 5.1 & 100 & 79 & 0.82 & 33.1 & 0.14 & 0.386 & 2.20 & 6.68 & 2.6 & 0.1256 & 1.46 & 0.829 & 2103 & 39 & 2037 & 26 & -3 \\
\hline 6.1 & 122 & 103 & 0.87 & 21.5 & 0.12 & 0.205 & 2.30 & 2.34 & 2.8 & 0.0825 & 1.72 & 0.797 & 1204 & 25 & 1257 & 34 & 4 \\
\hline 7.2 & 110 & 42 & 0.40 & 16.9 & 0.71 & 0.178 & 0.86 & 1.83 & 3.7 & 0.0744 & 3.63 & 0.229 & 1057 & 8 & 1052 & 73 & 0 \\
\hline 8.1 & 80 & 143 & 1.86 & 32.6 & 0.25 & 0.475 & 2.20 & 11.10 & 2.5 & 0.1694 & 1.20 & 0.880 & 2506 & 46 & 2552 & 20 & 2 \\
\hline 9.1 & 238 & 263 & 1.14 & 73.8 & 0.09 & 0.361 & 2.10 & 6.08 & 2.3 & 0.1223 & 0.83 & 0.931 & 1986 & 36 & 1990 & 15 & 0 \\
\hline 10.1 & 176 & 152 & 0.90 & 29.4 & 0.38 & 0.194 & 2.10 & 2.04 & 3.0 & 0.0763 & 2.06 & 0.717 & 1142 & 22 & 1104 & 41 & -4 \\
\hline 11.1 & 130 & 155 & 1.23 & 23.9 & 0.27 & 0.213 & 2.20 & 2.36 & 2.8 & 0.0802 & 1.83 & 0.762 & 1246 & 24 & 1201 & 36 & -4 \\
\hline 12.1 & 97 & 45 & 0.47 & 16.5 & 0.73 & 0.196 & 2.20 & 2.07 & 3.9 & 0.0768 & 3.19 & 0.572 & 1151 & 23 & 1117 & 64 & -3 \\
\hline 12.2 & 93 & 47 & 0.52 & 19.4 & 0.45 & 0.242 & 0.83 & 2.95 & 2.5 & 0.0883 & 2.40 & 0.326 & 1399 & 10 & 1390 & 46 & -1 \\
\hline 13.1 & 200 & 174 & 0.90 & 49.8 & 0.18 & 0.290 & 2.10 & 3.94 & 2.4 & 0.0988 & 1.16 & 0.873 & 1639 & 30 & 1601 & 22 & -2 \\
\hline 14.1 & 255 & 170 & 0.69 & 72.7 & 0.18 & 0.332 & 2.10 & 5.52 & 2.3 & 0.1207 & 0.84 & 0.928 & 1846 & 34 & 1967 & 15 & 6 \\
\hline $15.1^{*}$ & 55 & 63 & 1.20 & 15.3 & 0.41 & 0.324 & 2.30 & 5.58 & 11 & 0.1248 & 10.75 & 0.213 & 1811 & 37 & 2025 & 190 & 11 \\
\hline 16.1 & 177 & 138 & 0.81 & 26.8 & 0.19 & 0.176 & 2.10 & 1.76 & 2.7 & 0.0723 & 1.62 & 0.795 & 1046 & 20 & 995 & 33 & -5 \\
\hline 16.2 & 172 & 116 & 0.69 & 27.4 & 0.78 & 0.183 & 0.76 & 1.88 & 2.4 & 0.0743 & 2.25 & 0.319 & 1086 & 8 & 1050 & 45 & -3 \\
\hline 17.1 & 70 & 179 & 2.64 & 9.02 & 0.44 & 0.150 & 2.50 & 1.45 & 4.6 & 0.0701 & 3.86 & 0.548 & 900 & 21 & 930 & 79 & 3 \\
\hline 18.1 & 62 & 119 & 1.97 & 9.26 & 2.28 & 0.169 & 1.60 & 1.72 & 9.8 & 0.0739 & 9.67 & 0.161 & 1005 & 15 & 1038 & 200 & 3 \\
\hline 19.1 & 78 & 83 & 1.11 & 22.8 & 0.49 & 0.339 & 1.10 & 5.1 & 2.3 & 0.1090 & 1.99 & 0.484 & 1883 & 18 & 1784 & 36 & -6 \\
\hline 20.1 & 79 & 84 & 1.09 & 30 & 0.70 & 0.437 & 1.10 & 8.27 & 2.5 & 0.1371 & 2.27 & 0.423 & 2339 & 21 & 2191 & 39 & -7 \\
\hline 21.1 & 140 & 115 & 0.85 & 48.2 & 0.09 & 0.402 & 0.81 & 6.86 & 1.3 & 0.1239 & 0.97 & 0.638 & 2176 & 15 & 2014 & 17 & -8 \\
\hline 22.1 & 108 & 41 & 0.40 & 27.2 & 0.66 & 0.291 & 0.97 & 3.86 & 2.6 & 0.0961 & 2.37 & 0.379 & 1647 & 14 & 1549 & 44 & -6 \\
\hline 23.1 & 171 & 95 & 0.57 & 33.1 & 0.29 & 0.224 & 1.10 & 2.47 & 2.3 & 0.0801 & 2.02 & 0.461 & 1303 & 12 & 1198 & 40 & -9 \\
\hline
\end{tabular}

Notes: Errors are 1-sigma; $\mathrm{Pbc}$ and $\mathrm{Pb}^{*}$ indicate the common and radiogenic portions, respectively.

Error in Standard calibration was 0.50 and $0.36 \%$ (not included in above errors).

(1) Common $\mathrm{Pb}$ corrected using measured ${ }^{204} \mathrm{~Pb} /{ }^{206} \mathrm{~Pb}$ ratio.

* Analysis 15.1 has large error on the $207 \mathrm{~Pb} / 235 \mathrm{U}$ ratio and was not plotted on the U-Pb concordia diagram.

proximity of these deposits to the Palaeoproterozoic Porteirinha block suggests that it was likely the source of the sediments (Fig. 2).

\subsubsection{Diamictite from the Serra do Catuni Formation (MG05-01 and MG05-02)}

The detrital zircon grains separated from the matrix of diamictite MG05-01 sample are elongated to rounded, and their size range from 140 to $260 \mu \mathrm{m}$. The CL images show clear oscillatory zoning in most of the crystals (Fig. 5). Most of the grains are rounded indicating that they have been transported for long distances. However, 2 grains (spot $6.1=1.36 \mathrm{Ga}$, and spot $14.1=1.59 \mathrm{Ga}$; Fig. 5) show slightly euhedral shapes suggesting that their source rocks were not far from the depositional area. Forty three U-Pb ages were determined on thirty nine zircon grains (Table 4, Fig. 6). The ${ }^{207} \mathrm{~Pb} /{ }^{206} \mathrm{~Pb}$ ages ranged from $885 \pm 70 \mathrm{Ma}$ to $2740 \pm 22 \mathrm{Ma}$, and despite the strong variation in ages, an expressive number of grains concentrated into two main intervals of $1.15 \mathrm{Ga}$ to $1.4 \mathrm{Ga}$, and $1.8 \mathrm{Ga}$ to $2.2 \mathrm{Ga}$ (Fig. 7 ). The youngest age was determined on grain 20 where two analyses were carried out (spots 20.2 and 20.3; Table 4). Both of them are discordant and show ${ }^{207} \mathrm{~Pb} /{ }^{206} \mathrm{~Pb}$ ages of $885 \pm 70 \mathrm{Ma}$ (5\% reverse discordant) and $1021 \pm 51 \mathrm{Ma}$ (9\% discordant). However, their ${ }^{238} \mathrm{U} /{ }^{206} \mathrm{~Pb}$ ages are in agreement at $933 \pm 8 \mathrm{Ma}$, and we assume that this is the best estimate for the crystallization age of the zircons and, consequently, for the maximum depositional age of this glacial diamictite.

Zircon grains separated from the matrix of the glacial diamictite MG05-02 sample are subhedral to rounded, but few fragments of euhedral crystals are present. Their sizes range from 190 to $290 \mu \mathrm{m}$. Oscillatory zoning is viewed by the CL images; no metamorphic rims were observed (Fig. 5). Twenty one zircon grains were dated and the ages range from 1.1 to $2.2 \mathrm{Ga}$ (Table 5; Fig. 6). One grain yielded an older ${ }^{207} \mathrm{~Pb} /{ }^{206} \mathrm{~Pb}$ age but is highly discordant (19\%). Three main clusters are observed at $1.88 \mathrm{Ga}, 2.09 \mathrm{Ga}$, and $2.16 \mathrm{Ga}$ (Fig. 7). No Archean zircons were found in this sample. Two crystals with ages of 1.54 Ga (spot 6.1) and 1.8 Ga (spot 4.1) present euhedral shape and could indicate short transport from the source to the deposition site.
4.2.4. Mafic volcanic rock from the Lower Chapada Acauã Formation (MG05-03)

Most of the zircon grains display a rounded shape typical of detrital minerals. Their size range from 120 to $360 \mu \mathrm{m}$, but most of them are c. $200 \mu \mathrm{m}$ long. Oscillatory zoning is observed on the $\mathrm{CL}$ images (Fig. 5). Twenty three zircon grains from this sample were dated and the ages range from $960 \mathrm{Ma}$ to $2750 \mathrm{Ma}$ (Table 6; Fig. 6). Considering all data, three main clusters are observed at c. $1.4 \mathrm{Ga}$, $1.7 \mathrm{Ga}$, and $2.15 \mathrm{Ga}$ (Fig. 7). It is worth mentioning that the youngest ages were obtained on grain 11 (spots 11.1 and 11.2; Table 6), and both ages are discordant (19 and $-11 \%)$. However, the $U$ concentration on spot 11.1 is very low (22 ppm), and hence we prefer the ${ }^{238} \mathrm{U} /{ }^{206} \mathrm{~Pb}$ age $(1067 \pm 19 \mathrm{Ma})$ obtained on spot 11.2 (U concentration of $59 \mathrm{ppm}$ ) as the best estimation for the crystallization age of this grain. This youngest grain $(c .1 .1 \mathrm{Ga}$ ) has an age similar to detrital zircons from other mafic volcanic rock of the Lower Chapada Acauã Formation, which shows the same pillow structures (Babinski et al., 2005; Gradim et al., 2005).

\section{Discussion and correlations}

The evolution of the Macaúbas basin, precursor of the Araçuaí orogen, has to be interpreted together with its African counterpart, so that we briefly synthesize the stratigraphy of the West Congo belt. The West Congo Supergroup represents the precursor basin of the West Congo belt and includes, from base to top, the Tonian Zadinian and Mayumbian groups, a very thick succession of rift-related bimodal volcanic rocks and clastic sediments, and the West Congolian Group (Fig. 8) that comprises a basal rift-related siliciclastic succession (the Sansikwa Subgroup), followed by a glacio-marine diamictite with intercalations of transitional basalts (the Lower Mixtite Formation), a post-glacial carbonate-rich succession (the Haut Shiloango Subgroup), a second diamictite unit (the Upper Mixtite Formation), a post-glacial pelite-carbonate succession (the Schisto-Calcaire Subgroup) and molasse deposits (Frimmel et al., 2006; Pedrosa-Soares et al., 2008; Tack et al., 2001). The Lower and Upper Mixtite 


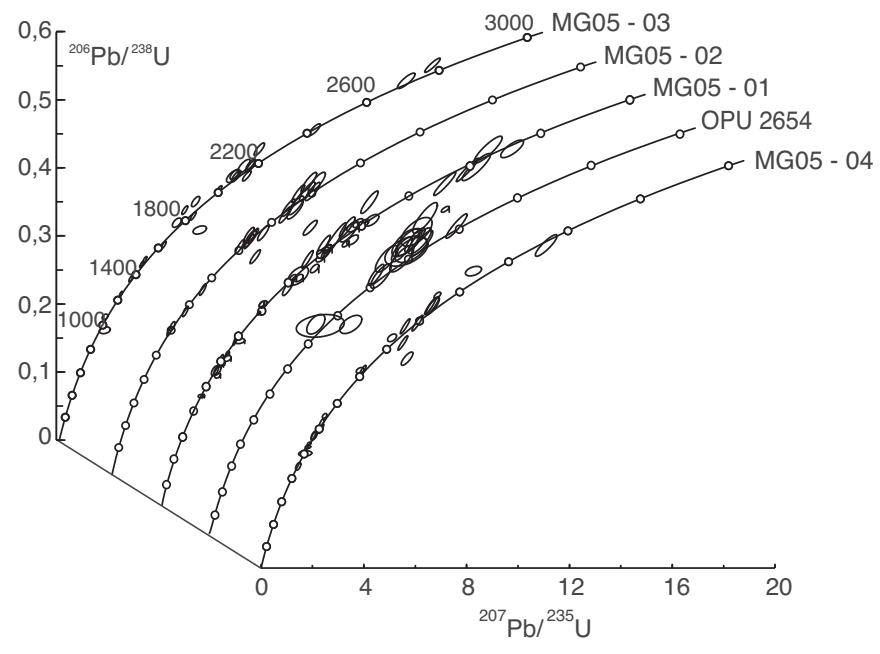

Fig. 6. U-Pb concordia diagrams for the five samples. Sample MG05-04; Quartzite from the Duas Barras Fm.; Sample OPU-2654: Quartzite from the Rio Peixe Bravo Fm.; Sample MG05-01: Diamictite from the Serra do Catuni Fm.; Sample MG05-02: Diamictite from the Serra do Catuni Fm.; and Sample MG05-03: Mafic volcanics.

Formations have been correlated with the old Cryogenian and young Cryogenian glacial events, respectively (Frimmel et al., 2006).

\subsection{Age, provenance and correlations of Macaúbas pre-glacial and glacigenic deposits}

The oldest pre-glacial units of the Macaúbas Group, named Matão, Duas Barras and Rio Peixe Bravo Formations (Fig. 2), comprise riftrelated fluvial to shallow marine sediments, deposited unconformably on the Archean-Palaeoproterozoic basement or atop sandstones of the Statherian-Mesoproterozoic Espinhaço Supergroup (Martins et al., 2008; Pedrosa-Soares et al., 2008). The maximum depositional age of the Duas Barras sandstones is $900 \pm 21 \mathrm{Ma}$, constrained by the youngest detrital zircons of sample MG05-04. The zircon age spectrum determined from this sample is large (900 to $2550 \mathrm{Ma}$; Figs. 6 and 7), with main peaks at 900-1250 Ma and 1.85-2.1 Ga. This large age distribution is similar to that of the Matão Formation, from which the youngest detrital zircon was dated at $1177 \pm 30 \mathrm{Ma}$ (Martins et al., 2008). In contrast, the Rio Peixe Bravo Formation shows an almost single source of $2.1 \mathrm{Ga}$ (Figs. 6 and 7). Such differences in age spectra for deposits close to each other suggest basin feeding from several sources and selective controls of erosion and sediment transport during the continental rift stage. Hence, though several sources provided sediments to the Duas Barras and Matão Formations, it seems that mostly Late Rhyacian rocks of the uplifted Porteirinha block fed the nearby Rio Peixe Bravo Formation (Fig. 2). The youngest detrital zircon of the Duas Barras sandstones indicates that the deposition of the Macaúbas Group took place after $900 \mathrm{Ma}$ ago.

The pre-glacial deposits of the Macaúbas Group have been tentatively correlated to the Sansikwa Subgroup of the West Congolian belt (Pedrosa-Soares et al., 2008), which is also a pre-glacial rift-related unit with a maximum depositional age of $923 \pm 43 \mathrm{Ma}$, and contains zircon grains with ages mainly between $900 \mathrm{Ma}$ and $1200 \mathrm{Ma}$ (Frimmel et al., 2006). However, in contrast with the Duas Barras age spectrum, only a few zircon grains of Archean and Palaeoproterozoic ages were observed in the Sansikwa Subgroup, indicating that in the African side Tonian to Stenian sources preferentially fed the basin. Many sources for the Tonian zircons are available in the West Congo belt including the thick Mayumbian rhyolitic lavas dated at $920 \pm 8 \mathrm{Ma}$ at the base and $912 \pm 7 \mathrm{Ma}$ at the top, the associated Mativa ( $924 \pm 25 \mathrm{Ma})$ and Bata Kimenga (917 $\pm 14 \mathrm{Ma}$ ) subvolcanic granites, and the $999 \pm 7 \mathrm{Ma}$ Noqui-type granites intruded in the Palaeoproterozic Kimezian base- ment and in the lowermost beds of the Zadinian Group (Tack et al., 2001). In contrast, Tonian igneous sources are not so abundant in the São Francisco craton and Araçuaí orogen, being limited to mafic dikes of 1000-900 Ma (D'Agrella Filho et al., 1990; Machado et al., 1989) and a few A-type granites dated at $875 \pm 9 \mathrm{Ma}$ (Silva et al., 2008). This can be explained by the model of an asymmetric continental rift with the thermal axis of the Tonian basin system located in the African side, as suggested by Pedrosa-Soares et al. (2008).

Igneous sources for the zircons with ages between $1.0 \mathrm{Ga}$ and $1.25 \mathrm{Ga}$ have not been found either in the São Francisco craton or in the West Congo belt. Some authors have advocated that zircons with these ages may derive from the Statherian-Mesoproterozoic EspinhaçoChapada Diamantina basin system that crops out in the São Francisco craton and Araçuaí orogen. In fact, a careful survey on the available geochronological data for the Espinhaço-Chapada Diamantina system shows a great prevalence of $\mathrm{U}-\mathrm{Pb}$ zircon ages between $1.75 \mathrm{Ga}$ and 1.5 Ga (Babinski et al., 1994, 1999; Battilani et al., 2005; Danderfer et al., 2009; Guimarães et al., 2005; Schobbenhaus et al., 1994). All the remaining geochronological data suggesting younger ages for deposition, except for those of Chemale et al. (2010), were obtained either on clay minerals or whole-rock samples by $\mathrm{Rb}-\mathrm{Sr}, \mathrm{K}-\mathrm{Ar}$ and $\mathrm{Pb}-\mathrm{Pb}$ radiometric methods (Távola et al., 1967; Jardim de Sá et al., 1976; Brito Neves et al., 1979; Macedo and Bonhomme, 1984; Babinski et al., 1993). These isotopic systems may have suffered partial resetting during the Brasiliano orogeny that affected several cratonic covers, yielding younger and/or geologically meaningless ages and should be interpreted with caution. The lack of source rocks with ages between 1.0 and $1.2 \mathrm{Ga}$ has also been mentioned on the African side (Batumike et al., 2009; Cox et al., 2004; Frimmel et al., 2006), except in the NamaquaNatal Province where ages of 1.1 to $1.3 \mathrm{Ga}$ are reported (Evans et al., 2007; Pettersson et al., 2007). However, according to most recent palaeogeographic reconstructions this lies on the Kalahari craton and was not attached to the Congo craton in the Tonian (e.g. Collins and Pisarevsky, 2005). According to available U-Pb data we can argue that the source of the large population of 1.0-1.25 Ga zircons has to be found elsewhere.

Detrital zircons with ages in the range 1.25-1.45 Ga, also present in the pre-glacial sediments of the Macaúbas Group, could have been transported from the Kibaran belt, located on the eastern margin of the Congo craton, in Central Africa (e.g., Tack et al., 1994; Trompette, 1994). The Irumide belt, in the southeast of the Congo craton, also has protoliths of 1.36-0.95 Ga (De Waele et al. 2006) and is feasibly a source of these zircons. Nevertheless, considering the distance between these regions and the study area in a Meso-Neoproterozoic palaeogeographic fit, it is hard to believe that they could be sources of detrital zircons for the Macaúbas Group. On the other hand, U-Pb data for the Vazante (Rodrigues, 2008) and Andrelândia (Valeriano et al., 2004; Valladares et al., 2004) Groups in the Brasília belt, located west of the São Francisco craton (Fig. 1), also show detrital zircons with ages ranging from $1.0 \mathrm{Ga}$ to $1.6 \mathrm{Ga}$, but mainly in the $1.2-1.3 \mathrm{Ga}$ interval. Granitoids from the Brasília belt have been dated at c. $1.2 \mathrm{Ga}$ (Klein, 2008) and could represent one of the sources. However, the occurrence of these zircons in both sides of the São Francisco craton strongly suggests that Mesoproterozoic sources are in the São Francisco craton, and probably hidden by Neoproterozoic and Phanerozoic covers.

The massive diamictites of the Serra do Catuni Formation represent the lowermost glacigenic deposits of the Macaúbas Group (Fig. 2), deposited in proximal glacio-marine environments. They grade upwards and laterally to the stratified diamictites of the Lower Chapada Acauã Formation (Karfunkel and Hoppe 1988; Martins et al., 2008; PedrosaSoares et al., 1992, 2008). The maximum depositional age of the Serra do Catuni diamictites was given by the youngest zircon dated at $933 \pm 8 \mathrm{Ma}$ (Table 4; Figs. 6 and 7). The source of these zircons is considered to be the volcanic pile of the Zadinian and Mayumbian groups, and related granites (Tack et al., 2001). The main rock sources of these diamictites (samples MG05-01 and MG05-02) are in the age interval of 0.9-1.3 Ga and 1.8- 


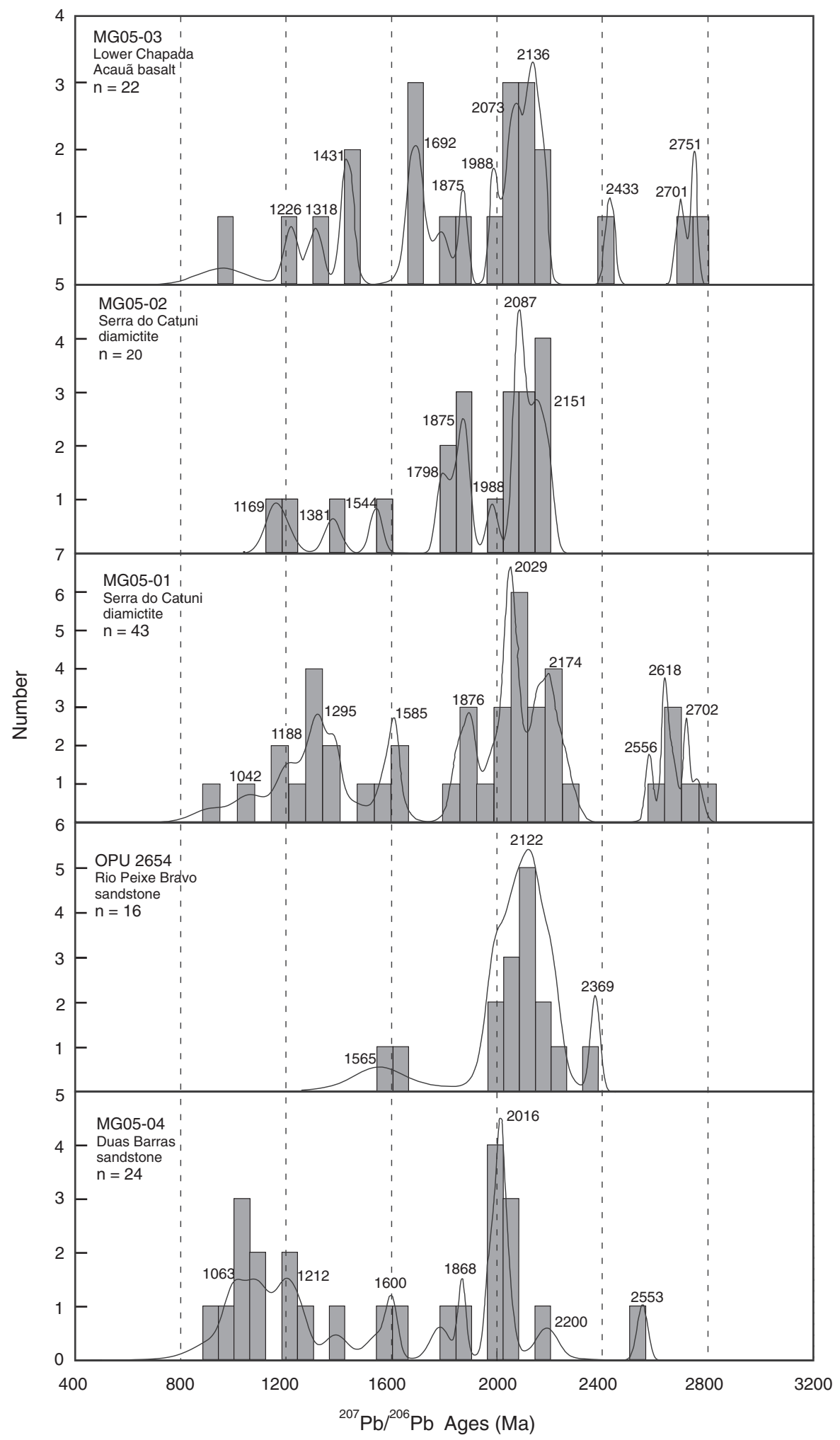

Fig. 7. Frequency histogram and probability curves of zircon $\mathrm{Pb} / \mathrm{Pb}$ ages ( $<15 \%$ discordant) for samples of the Macaúbas Group.

$2.2 \mathrm{Ga}$, with peaks at $1.3 \mathrm{Ga}, 1.6 \mathrm{Ga}, 1.87 \mathrm{Ga}, 2.0 \mathrm{Ga}, 2.1 \mathrm{Ga}$ and $2.6 \mathrm{Ga}$ (Figs. 6 and 7). Here again the 1.0 to 1.3 Ga sources are hard to identify, but the older ones are common in the Espinhaço Supergroup (1.5 to $1.75 \mathrm{Ga}$ ), and in the basement rocks of the São Francisco-Congo craton, and in the Porteirinha and Guanhães blocks (Fig. 2).

The correlation of the Jequitaí and Serra do Catuni formations, as a west to east lateral succession from glacio-terrestrial to glacio-marine facies, is rather a consensus in the literature; the first unit including most of the glacio-terrestrial deposits left by the glaciers on the São Francisco craton (e.g., Karfunkel and Hoppe, 1988; Martins-Neto et al., 2001; Pedrosa-Soares et al., 2008; Uhlein et al., 1999). This interpretation is also supported by the age spectra of detrital zircons from both formations, as shown in this paper, and by Buchwaldt et al. (1999) and Rodrigues (2008). 
Table 3

U-Pb SHRIMP data from detrital zircons of sample OPU 2654 (Rio Peixe Bravo Formation).

\begin{tabular}{|c|c|c|c|c|c|c|c|c|c|c|c|c|c|c|c|c|c|}
\hline \multirow{2}{*}{$\begin{array}{l}\text { Grain. } \\
\text { spot }\end{array}$} & \multirow{2}{*}{$\begin{array}{l}\mathrm{U} \\
(\mathrm{ppm})\end{array}$} & \multirow{2}{*}{$\begin{array}{l}\text { Th } \\
(\mathrm{ppm})\end{array}$} & \multirow{2}{*}{$\begin{array}{l}{ }^{232} \mathrm{Th} / \\
{ }^{238} \mathrm{U}\end{array}$} & \multirow{2}{*}{$\begin{array}{l}{ }^{206} \mathrm{~Pb}^{*} \\
\text { (ppm) }\end{array}$} & \multirow[t]{2}{*}{${ }^{206} \mathrm{Pbc} \%$} & \multicolumn{6}{|c|}{ Radiogenic ratios } & \multicolumn{5}{|c|}{ Age (Ma) } & \multirow[b]{2}{*}{ \% Disc } \\
\hline & & & & & & ${ }^{206} \mathrm{~Pb} /{ }^{238} \mathrm{U}$ & $\pm \%$ & ${ }^{207} \mathrm{~Pb} /{ }^{235} \mathrm{U}$ & $\pm \%$ & ${ }^{207} \mathrm{~Pb} /{ }^{206} \mathrm{~Pb}$ & \pm & $\rho$ & ${ }^{206} \mathrm{~Pb} /{ }^{238} \mathrm{U}$ & \pm & ${ }^{207} \mathrm{~Pb} /{ }^{206} \mathrm{~Pb}$ & \pm & \\
\hline 1.1 & 104 & 65 & 0.64 & 28.3 & 2.29 & 0.309 & 2.9 & 5.45 & 5.2 & 0.128 & 4.3 & 0.556 & 1735 & 44 & 2069 & 76 & 16 \\
\hline 2.1 & 49 & 19 & 0.40 & 18.4 & 0.75 & 0.430 & 3.2 & 7.57 & 4.7 & 0.128 & 3.4 & 0.682 & 2306 & 62 & 2067 & 60 & -12 \\
\hline 3.1 & 58 & 36 & 0.64 & 21.8 & 0.56 & 0.431 & 3.0 & 7.69 & 4.3 & 0.129 & 3.1 & 0.703 & 2311 & 59 & 2090 & 54 & -11 \\
\hline 4.1 & 137 & 131 & 0.98 & 50.0 & 0.72 & 0.420 & 2.9 & 7.43 & 3.6 & 0.128 & 2.2 & 0.797 & 2262 & 55 & 2074 & 38 & -9 \\
\hline 5.1 & 71 & 92 & 1.35 & 23.2 & 0.39 & 0.381 & 3.1 & 6.62 & 4.0 & 0.126 & 2.4 & 0.790 & 2079 & 56 & 2044 & 43 & -2 \\
\hline 6.1 & 41 & 19 & 0.49 & 14.4 & 0.20 & 0.406 & 3.2 & 6.83 & 4.2 & 0.122 & 2.7 & 0.758 & 2197 & 59 & 1986 & 49 & -11 \\
\hline 7.1 & 65 & 45 & 0.71 & 24.3 & 0.11 & 0.433 & 2.9 & 8.12 & 3.7 & 0.136 & 2.2 & 0.800 & 2318 & 57 & 2178 & 38 & -6 \\
\hline 8.1 & 105 & 13 & 0.12 & 39.0 & 0.30 & 0.430 & 2.8 & 8.21 & 3.3 & 0.139 & 1.7 & 0.850 & 2305 & 54 & 2210 & 30 & -4 \\
\hline 9.1 & 54 & 63 & 1.20 & 14.4 & 0.82 & 0.309 & 3.1 & 4.09 & 5.7 & 0.096 & 4.7 & 0.549 & 1737 & 47 & 1548 & 89 & -12 \\
\hline 10.1 & 45 & 42 & 0.96 & 12.5 & 5.32 & 0.307 & 3.6 & 4.27 & 14.0 & 0.101 & 14.0 & 0.252 & 1725 & 55 & 1640 & 260 & -5 \\
\hline 11.1 & 49 & 24 & 0.51 & 17.9 & 2.93 & 0.418 & 3.5 & 7.60 & 7.2 & 0.132 & 6.3 & 0.487 & 2250 & 67 & 2125 & 110 & -6 \\
\hline 12.1 & 77 & 42 & 0.57 & 28.3 & 2.41 & 0.419 & 2.9 & 7.78 & 5.2 & 0.135 & 4.3 & 0.563 & 2258 & 56 & 2157 & 75 & -5 \\
\hline 13.1 & 47 & 27 & 0.59 & 18.3 & 1.00 & 0.446 & 3.1 & 7.99 & 5.0 & 0.130 & 3.9 & 0.628 & 2378 & 63 & 2096 & 68 & -13 \\
\hline 14.1 & 56 & 19 & 0.36 & 19.5 & 0.32 & 0.406 & 3.2 & 7.42 & 4.1 & 0.132 & 2.6 & 0.775 & 2199 & 59 & 2130 & 46 & -3 \\
\hline 15.1 & 120 & 35 & 0.30 & 45.0 & 0.35 & 0.434 & 2.7 & 7.92 & 3.2 & 0.132 & 1.7 & 0.854 & 2324 & 53 & 2130 & 29 & -9 \\
\hline 16.1 & 62 & 26 & 0.44 & 24.7 & 0.00 & 0.467 & 3.2 & 8.33 & 3.8 & 0.129 & 2.0 & 0.850 & 2470 & 66 & 2089 & 35 & -18 \\
\hline 17.1 & 158 & 127 & 0.83 & 52.2 & 0.32 & 0.382 & 2.7 & 6.43 & 3.1 & 0.122 & 1.6 & 0.862 & 2087 & 48 & 1985 & 28 & -5 \\
\hline 18.1 & 235 & 85 & 0.37 & 91.9 & 0.14 & 0.455 & 2.6 & 9.54 & 2.8 & 0.152 & 1.1 & 0.928 & 2417 & 53 & 2370 & 18 & -2 \\
\hline
\end{tabular}

Notes: Errors are 1-sigma; $\mathrm{Pbc}$ and $\mathrm{Pb}^{*}$ indicate the common and radiogenic portions, respectively.

Error in Standard calibration was 0.58\% (not included in above errors).

1) Common $\mathrm{Pb}$ corrected using measured ${ }^{204} \mathrm{~Pb} /{ }^{206} \mathrm{~Pb}$ ratio.

The Lower Chapada Acauã Formation, a thick glacio-marine pile of debris flow deposits (the stratified diamictites) interbedded with sand-pelite turbidites, covers the proximal Serra do Catuni diamictites but also represents a distal equivalent of them, depicting a continuous record of the same glacial event (Karfunkel and Hoppe, 1988; Pedrosa-Soares et al., 1992, 1998, 2008; Martins-Neto et al., 2001; Uhlein et al., 2007; Martins et al., 2008). Rift-related, mafic volcanic rocks with pillow structures and transitional geochemical signature occur interbedded in the Lower Chapada Acauã Formation (Gradim et al., 2005). Attempts to date them were not successful due to the lack of original igneous zircon crystals (Babinski et al., 2005; this work). The youngest detrital grain dated here at 1067 Ma sets the maximum age of the volcanism. The presence of detrital zircons ranging from $1.07 \mathrm{Ga}$ to $2.75 \mathrm{Ga}$ represents the variety of rocks assimilated by the mafic magma and, therefore, available in the sediment pile crossed by it. The Sm-Nd $\mathrm{T}_{\mathrm{DM}}$ model age of $1.7 \mathrm{Ga}$ also suggests that the magma was contaminated by the continental crust. These tholeiitic basalts are present in other parts of the Lower Chapada Acauã Formation and show similar Sm-Nd $\mathrm{T}_{\mathrm{DM}}$ model ages and detrital zircons ranging from 1.16 to $2.67 \mathrm{Ga}$ (Babinski et al., 2005; Gradim et al., 2005). In the West Congo belt, basalts with pillow structures interlayered with diamictites of the Lower Mixtite Formation, as well as associated feeder dykes and sills, also show a rift-related, transitional geochemical signature (De Paepe et al., 1975; Kampunzu et al., 1991), but they are undated (Frimmel et al., 2006). Based on the striking similarity of this volcanism and stratigraphic relation in both Macaúbas and West Congolian basins, Pedrosa-Soares et al. (2008) suggested the correlation between the Lower Chapada Acauã and Lower Mixtite formations.

Most of the diamictite-turbidite package of the Lower Chapada Acauã Formation seems to represent resedimented mass flows supplied by the glaciated onshore region (Gradim et al., 2005; Martins et al., 2008; Martins-Neto et al., 2001; Uhlein et al., 1999), so that it can be related to the deglaciation phase of the Macaúbas basin. This succession is transgressive over the Serra do Catuni Formation, contains a few carbonate lenses at its top, and passes upward and laterally to successions completely free of diamictites-the Upper Chapada Acauã and Ribeirão da Folha Formations. This suggests a correlation of the Lower Chapada Acauã Formation with the Carrancas diamictite (Pedrosa-Soares et al., 2008), which is covered by the unit that includes the $c .740$ Ma cap carbonate on the São Francisco craton (Babinski et al., 2007).
It is worth mentioning that the Sm-Nd model ages show older ages towards the top of the sedimentary succession (Table 1 ). The lowermost unit, the Duas Barras Formation, yields the younger $\mathrm{T}_{\mathrm{DM}}$ ages of 1.8$1.9 \mathrm{Ga}$. Up-section the $\mathrm{T}_{\mathrm{DM}}$ ages become older, ranging from 2.2 to $2.3 \mathrm{Ga}$ in the diamictites of the Serra do Catuni and Lower Chapada Acauã Formations. The older $\mathrm{T}_{\mathrm{DM}}$ age $(2.5 \mathrm{Ga})$ was determined on a sandstone of the diamictite-free Upper Chapada Acauã Formation. These Sm-Nd model ages suggest that sources with older ages (Archean protoliths) had a higher contribution in the upper units of the Macaúbas basin. This behavior could be explained by the evolution of the rift. In the early rift stages, the main sources of sediments were the 900-1000 Ma volcanic pile of the Zadinian and Mayumbian groups and related anorogenic granites eroded from uplifted shoulders and internal horsts of the rift. These are common sources in the basal units of the Macaúbas and West Congolian groups. As the basin evolved, these Neoproterozoic sources were replaced by older sources-mainly Palaeoproterozoic and Archean ones. This is observed in the Serra do Catuni and Lower Chapada Acauã Formations, which have older $\mathrm{T}_{\mathrm{DM}}$ ages compared to the pre-glacial units of the Macaúbas Group. In the West Congo Belt, the 1.8-1.9 Ga $\mathrm{T}_{\mathrm{DM}}$ ages are constant along the sedimentary pile, but the presence of Archean and Palaeoproterozoic zircons, although not very common, significantly increases in the Haut Shiloango Subgroup (40\%) compared to the Sansikwa Subgroup (15\%), (Frimmel et al., 2006). Because $\mathrm{T}_{\mathrm{DM}}$ ages on samples from the West Congo belt are all around 1.8-1.9 Ga, and the Archean and Palaeoproterozoic sources are much less important compared to the Tonian ones, we speculate that the older components have come mostly from the basement of the São Francisco craton.

\subsection{Possible correlations of the Macaúbas diamictites with Neoproterozoic glacial events}

The U-Pb ages obtained on the lower formations of the Macaúbas Group indicate that their deposition took place after $900 \mathrm{Ma}$ ago, but do not give any direct constraint regarding to which Neoproterozoic glaciation these deposits are related. Also, the Jequitaí, Carrancas and Bebedouro diamictites, deposited on the São Francisco craton (Fig. 1), only contain zircons older than $875 \mathrm{Ma}$ (Buchwaldt et al., 1999; Figueiredo et al., 2009; Rodrigues, 2008). Since the Carrancas and Jequitaí diamictites underlie the pelite-carbonate cratonic cover that includes a basal cap carbonate dated at $740 \pm 22 \mathrm{Ma}$ (Babinski et al., 2007), we suggest that the correlative Macaúbas diamictites were deposited during the Early Cryogenian (known as old Cryogenian) glacial event. 
Table 4

U-Pb SHRIMP data from detrital zircons of sample MG05-01 (Serra do Catuni Formation)

\begin{tabular}{|c|c|c|c|c|c|c|c|c|c|c|c|c|c|c|c|c|c|}
\hline \multirow{2}{*}{$\begin{array}{l}\text { Grain. } \\
\text { spot }\end{array}$} & \multirow{2}{*}{$\begin{array}{l}\mathrm{U} \\
(\mathrm{ppm})\end{array}$} & \multirow{2}{*}{$\begin{array}{l}\text { Th } \\
\text { (ppm) }\end{array}$} & \multirow{2}{*}{$\begin{array}{l}{ }^{232} \mathrm{Th} / \\
{ }^{238} \mathrm{U}\end{array}$} & \multicolumn{8}{|c|}{ Radiogenic ratios } & \multirow[b]{2}{*}{$\rho$} & \multicolumn{4}{|c|}{ Age (Ma) } & \multirow{2}{*}{$\begin{array}{l}\% \\
\text { Disc. }\end{array}$} \\
\hline & & & & $\begin{array}{l}{ }^{206} \mathrm{~Pb}^{*} \\
(\mathrm{ppm})\end{array}$ & $\begin{array}{c}{ }^{206} \mathrm{Pbc} \\
\%\end{array}$ & $\begin{array}{c}{ }^{206} \mathrm{~Pb} / \\
{ }^{238} \mathrm{U}\end{array}$ & $\pm \%$ & $\begin{array}{c}{ }^{207} \mathrm{~Pb} / \\
{ }^{235} \mathrm{U}\end{array}$ & $\pm \%$ & $\begin{array}{l}{ }^{207} \mathrm{~Pb} / \\
{ }^{206} \mathrm{~Pb}\end{array}$ & \pm & & $\begin{array}{l}{ }^{206} \mathrm{~Pb} / \\
{ }^{238} \mathrm{U}\end{array}$ & \pm & $\begin{array}{l}{ }^{207} \mathrm{~Pb} / \\
{ }^{206} \mathrm{~Pb}\end{array}$ & $\overline{ \pm}$ & \\
\hline 1.1 & 104 & 58 & 0.57 & 36.4 & 0.09 & 0.405 & 2.5 & 7.190 & 2.8 & 0.129 & 1.3 & 0.886 & 2190 & 46 & 2084 & 23 & 5 \\
\hline 2.1 & 215 & 111 & 0.54 & 66 & 0.47 & 0.357 & 2.4 & 5.650 & 2.6 & 0.115 & 1 & 0.921 & 1969 & 41 & 1875 & 18 & -5 \\
\hline 3.1 & 112 & 141 & 1.30 & 31.8 & 0.08 & 0.330 & 0.99 & 5.083 & 1.8 & 0.112 & 1.5 & 0.549 & 1837 & 16 & 1829 & 27 & 0 \\
\hline 4.1 & 149 & 73 & 0.51 & 26 & 0.21 & 0.204 & 0.92 & 2.353 & 2.0 & 0.084 & 1.8 & 0.447 & 1196 & 10 & 1286 & 36 & 7 \\
\hline 5.1 & 102 & 56 & 0.56 & 32.6 & 0.14 & 0.370 & 1.0 & 6.300 & 1.9 & 0.124 & 1.5 & 0.551 & 2027 & 18 & 2010 & 27 & -1 \\
\hline 6.1 & 103 & 43 & 0.43 & 18.9 & 0.12 & 0.211 & 1.3 & 2.535 & 3.5 & 0.087 & 3.2 & 0.376 & 1235 & 15 & 1363 & 63 & 9 \\
\hline 7.1 & 114 & 186 & 1.69 & 36.5 & 0.71 & 0.372 & 1.2 & 6.400 & 1.7 & 0.125 & 1.2 & 0.692 & 2040 & 21 & 2025 & 22 & -1 \\
\hline 8.1 & 84 & 44 & 0.55 & 29.2 & 0.25 & 0.405 & 1.1 & 7.420 & 2.1 & 0.133 & 1.8 & 0.526 & 2190 & 21 & 2138 & 32 & -2 \\
\hline 9.1 & 158 & 79 & 0.52 & 51.7 & 0.09 & 0.380 & 0.82 & 7.135 & 1.3 & 0.136 & 0.96 & 0.649 & 2077 & 15 & 2179 & 17 & 5 \\
\hline 10.1 & 139 & 76 & 0.56 & 34.9 & 0.38 & 0.291 & 0.91 & 3.870 & 1.8 & 0.096 & 1.5 & 0.519 & 1647 & 13 & 1555 & 28 & -6 \\
\hline 10.2 & 82 & 46 & 0.58 & 20.6 & 0.27 & 0.291 & 1.2 & 3.920 & 2.6 & 0.098 & 2.3 & 0.473 & 1645 & 18 & 1583 & 43 & -4 \\
\hline 11.1 & 250 & 241 & 0.99 & 92.8 & 0.73 & 0.431 & 0.67 & 11.010 & 0.9 & 0.185 & 0.64 & 0.724 & 2310 & 13 & 2700 & 11 & 14 \\
\hline 12.1 & 141 & 410 & 3.00 & 24.6 & 0.45 & 0.202 & 1.2 & 2.290 & 2.5 & 0.082 & 2.3 & 0.455 & 1185 & 12 & 1253 & 44 & 5 \\
\hline 13.1 & 98 & 38 & 0.40 & 20.1 & 0.18 & 0.237 & 1.1 & 3.000 & 4.4 & 0.092 & 4.3 & 0.242 & 1370 & 13 & 1465 & 82 & 6 \\
\hline 14.1 & 316 & 122 & 0.40 & 75.5 & 0.18 & 0.278 & 0.64 & 3.752 & 1.1 & 0.098 & 0.91 & 0.576 & 1580 & 9 & 1586 & 17 & 0 \\
\hline 15.1 & 52 & 21 & 0.41 & 18.6 & 0.41 & 0.415 & 1.4 & 8.150 & 2.2 & 0.143 & 1.8 & 0.609 & 2237 & 26 & 2257 & 31 & 1 \\
\hline 16.1 & 101 & 140 & 1.43 & 32.4 & 0.19 & 0.372 & 1.0 & 6.440 & 1.7 & 0.125 & 1.3 & 0.607 & 2041 & 18 & 2035 & 24 & 0 \\
\hline 17.1 & 105 & 159 & 1.56 & 32.4 & 0.78 & 0.359 & 0.99 & 6.140 & 1.8 & 0.124 & 1.5 & 0.556 & 1976 & 17 & 2017 & 26 & 2 \\
\hline 18.1 & 159 & 64 & 0.41 & 29.9 & 0.44 & 0.219 & 0.87 & 2.541 & 1.7 & 0.084 & 1.5 & 0.509 & 1276 & 10 & 1298 & 29 & 2 \\
\hline 19.1 & 65 & 24 & 0.38 & 22.8 & 2.28 & 0.409 & 1.2 & 7.800 & 1.8 & 0.139 & 1.4 & 0.648 & 2208 & 22 & 2209 & 24 & 0 \\
\hline 20.2 & 83 & 221 & 2.75 & 11.2 & 0.49 & 0.156 & 0.96 & 1.472 & 3.6 & 0.069 & 3.4 & 0.269 & 933 & 8 & 885 & 71 & -5 \\
\hline 20.3 & 57 & 169 & 3.07 & 7.61 & 0.70 & 0.156 & 1.1 & 1.573 & 2.7 & 0.073 & 2.5 & 0.410 & 933 & 10 & 1021 & 51 & 9 \\
\hline 21.1 & 82 & 56 & 0.71 & 28.9 & 0.09 & 0.411 & 1.1 & 7.620 & 1.7 & 0.135 & 1.3 & 0.620 & 2217 & 20 & 2158 & 23 & -3 \\
\hline 22.1 & 80 & 49 & 0.64 & 25.1 & 0.66 & 0.365 & 1.1 & 6.280 & 2.0 & 0.125 & 1.7 & 0.543 & 2004 & 19 & 2027 & 30 & 1 \\
\hline 23.1 & 48 & 48 & 1.03 & 21.7 & 0.29 & 0.520 & 1.7 & 13.610 & 2.1 & 0.190 & 1.4 & 0.771 & 2699 & 36 & 2741 & 22 & 2 \\
\hline 24.1 & 103 & 131 & 1.32 & 30.4 & 0.14 & 0.344 & 1.2 & 5.920 & 1.8 & 0.125 & 1.4 & 0.664 & 1904 & 20 & 2029 & 24 & 6 \\
\hline 25.1 & 97 & 90 & 0.96 & 15.5 & 0.35 & 0.186 & 1.4 & 2.149 & 3.4 & 0.084 & 3.2 & 0.395 & 1100 & 14 & 1288 & 62 & 15 \\
\hline 26.1 & 63 & 51 & 0.83 & 20.9 & 0.19 & 0.386 & 1.2 & 7.400 & 2.0 & 0.139 & 1.6 & 0.616 & 2103 & 22 & 2216 & 27 & 5 \\
\hline 27.1 & 83 & 36 & 0.45 & 23.5 & 0.20 & 0.330 & 1.1 & 5.310 & 2.1 & 0.117 & 1.8 & 0.513 & 1837 & 17 & 1909 & 32 & 4 \\
\hline 28.1 & 251 & 74 & 0.30 & 51.7 & 0.16 & 0.239 & 2.3 & 2.858 & 2.6 & 0.087 & 1.1 & 0.902 & 1380 & 29 & 1357 & 21 & -2 \\
\hline 29.1 & 53 & 33 & 0.64 & 15.4 & 1.24 & 0.332 & 2.7 & 5.270 & 5.0 & 0.115 & 4.2 & 0.546 & 1849 & 44 & 1882 & 75 & 2 \\
\hline 30.1 & 103 & 87 & 0.87 & 33.6 & 0.37 & 0.378 & 2.4 & 6.270 & 2.7 & 0.120 & 1.2 & 0.896 & 2068 & 43 & 1960 & 21 & -6 \\
\hline 31.1 & 83 & 20 & 0.26 & 13.8 & 0.80 & 0.193 & 2.5 & 2.043 & 4.4 & 0.077 & 3.6 & 0.568 & 1137 & 26 & 1117 & 73 & -2 \\
\hline 32.1 & 264 & 71 & 0.28 & 47.6 & 0.32 & 0.209 & 2.4 & 2.277 & 2.9 & 0.079 & 1.7 & 0.805 & 1225 & 26 & 1170 & 34 & -5 \\
\hline 33.1 & 70 & 48 & 0.71 & 24.2 & 0.95 & 0.397 & 2.6 & 7.250 & 3.2 & 0.132 & 1.9 & 0.811 & 2157 & 47 & 2130 & 32 & -1 \\
\hline 34.1 & 43 & 22 & 0.53 & 18.4 & 0.26 & 0.493 & 2.7 & 12.210 & 3.0 & 0.180 & 1.3 & 0.894 & 2583 & 57 & 2650 & 22 & 3 \\
\hline 34.2 & 66 & 43 & 0.67 & 29.6 & 0.36 & 0.518 & 2.5 & 12.660 & 2.8 & 0.177 & 1.3 & 0.883 & 2692 & 55 & 2627 & 22 & -2 \\
\hline 35.1 & 83 & 57 & 0.70 & 27.7 & 0.45 & 0.384 & 4.5 & 6.660 & 4.8 & 0.126 & 1.5 & 0.946 & 2096 & 81 & 2039 & 27 & -3 \\
\hline 36.1 & 137 & 58 & 0.43 & 23 & 1.02 & 0.193 & 2.4 & 2.142 & 4.3 & 0.080 & 3.5 & 0.566 & 1140 & 25 & 1204 & 70 & 5 \\
\hline 37.1 & 145 & 66 & 0.47 & 58.7 & 0.35 & 0.468 & 2.4 & 10.980 & 2.6 & 0.170 & 0.85 & 0.943 & 2475 & 50 & 2559 & 14 & 3 \\
\hline 37.2 & 203 & 150 & 0.76 & 85.3 & 0.21 & 0.489 & 2.3 & 11.860 & 2.4 & 0.176 & 0.66 & 0.963 & 2565 & 49 & 2616 & 11 & 2 \\
\hline 38.1 & 101 & 70 & 0.72 & 27.6 & 0.38 & 0.316 & 2.5 & 4.890 & 2.9 & 0.112 & 1.6 & 0.847 & 1768 & 39 & 1838 & 28 & 4 \\
\hline 39.1 & 96 & 54 & 0.58 & 36.6 & 0.43 & 0.441 & 2.5 & 8.050 & 2.7 & 0.132 & 1.2 & 0.897 & 2355 & 49 & 2130 & 21 & -11 \\
\hline
\end{tabular}

Notes: Errors are 1-sigma; $\mathrm{Pbc}$ and $\mathrm{Pb}^{*}$ indicate the common and radiogenic portions, respectively.

Error in Standard calibration was $0.52,0.30$ and $0.90 \%$ (not included in above errors).

(1) Common $\mathrm{Pb}$ corrected using measured ${ }^{204} \mathrm{~Pb} /{ }^{206} \mathrm{~Pb}$ ratio.

Based on recent ${ }^{87} \mathrm{Sr} /{ }^{86} \mathrm{Sr}$ data (Frimmel et al., 2006) and previous data (Frimmel et al., 2002) from carbonates, the Haut Shiloango Subgroup has been interpreted as a post-Sturtian open marine carbonate platform. The carbonates of the Schisto-Calcaire unit are distinguished by negative $\delta^{13} \mathrm{C}$ values $(-1$ to $-3 \%$ ), which are interpreted as a signature of post-glacial cap carbonates above the Upper Mixtite Formation. Although no radiometric age control exists for these rocks, they must be older than $558 \pm 29 \mathrm{Ma}$, which is the maximum depositional age for the overlying Inkisi Subgroup. An upper age limit is also given by the metamorphic event that affected the whole West Congolian Group at c. 566 Ma (Frimmel et al., 2006).

If the U-Pb SHRIMP ages on detrital zircons recovered from the Haut Shiloango Subgroup (Frimmel et al., 2006) are considered, another scenario can be suggested. The youngest detrital zircon dated from the Haut Shiloango Group is $547 \pm 45 \mathrm{Ma}$ ( $5 \%$ discordant). Thus, considering the error, the maximum depositional age of the Haut Shiloango would be $592 \mathrm{Ma}$. If this is correct, the Upper Mixtite Formation which is in higher stratigraphic position would be correlated to the Gaskiers glaciation event (Bowring et al., 2003). Some samples of the Haut Shiloango Subgroup present ${ }^{87} \mathrm{Sr} /{ }^{86} \mathrm{Sr}$ ratios of 0.7071 that could be correlated to post-old Cryogenian values. However, the $\delta^{13} \mathrm{C}$ values are very positive $(+3$ to $+8 \%$ ) and could not represent those of post-old Cryogenian cap carbonates (which are typified by negative $\delta^{13} \mathrm{C}$ values). This would imply in a hiatus in the middle of the Haut Shiloango Subgroup, the lowest part being Early Cryogenian and the upper part being younger than $590 \mathrm{Ma}$.

The same scenario has been recently identified in the Bambuí Group, a pelite-carbonate cover of the São Francisco craton. Cap carbonates of the Sete Lagoas Formation, the lowermost unit of the Bambuí Group, yielded a Pb-Pb isochron age of $740 \pm 22 \mathrm{Ma}$ (Babinski et al., 2007), supporting a old Cryogenian-age for the underlying glacial deposits. At the middle of the Sete Lagoas Formation a sharp shift on $\delta^{13} \mathrm{C}$ values is observed, increasing from 0 to $+12 \%$. This shift is accompanied by a marked change in sedimentary facies, with increase in detrital input (Kuchenbecker et al., 2010; Vieira et al., 2007a). Detrital zircons $(n=63)$ recovered from pelites above the C-isotopic shift yielded U$\mathrm{Pb}$ ages ranging from $610 \mathrm{Ma}$ to $850 \mathrm{Ma}$ (Rodrigues, 2008). These data suggest that the lowermost part of the Sete Lagoas Formation represents a post-Sturtian cap carbonate, and a hiatus of $c .130$ m.y. exists between the lower and the middle-upper part of the Sete Lagoas Formation. A 
Table 5

U-Pb SHRIMP data from detrital zircons of sample MG05-02 (Serra do Catuni Formation).

\begin{tabular}{|c|c|c|c|c|c|c|c|c|c|c|c|c|c|c|c|c|c|}
\hline \multirow{2}{*}{$\begin{array}{l}\text { Grain. } \\
\text { spot }\end{array}$} & \multirow{2}{*}{$\begin{array}{l}\mathrm{U} \\
(\mathrm{ppm})\end{array}$} & \multirow{2}{*}{$\begin{array}{l}\text { Th } \\
\text { (ppm) }\end{array}$} & \multirow{2}{*}{$\begin{array}{l}{ }^{232} \mathrm{Th} \\
{ }^{238} \mathrm{U}\end{array}$} & \multirow{2}{*}{$\begin{array}{l}{ }^{206} \mathrm{~Pb}^{*} \\
(\mathrm{ppm})\end{array}$} & \multirow{2}{*}{$\begin{array}{l}{ }_{\%}^{206} \mathrm{Pbc} \\
\%\end{array}$} & \multicolumn{6}{|c|}{ Radiogenic ratios } & \multirow[b]{2}{*}{$\rho$} & \multicolumn{4}{|c|}{ Age (Ma) } & \multirow{2}{*}{$\begin{array}{l}\% \\
\text { Disc. }\end{array}$} \\
\hline & & & & & & $\begin{array}{l}{ }^{206} \mathrm{~Pb} / \\
{ }^{238} \mathrm{U}\end{array}$ & $\pm \%$ & $\begin{array}{l}{ }^{207} \mathrm{~Pb} / \\
{ }^{235} \mathrm{U}\end{array}$ & $\pm \%$ & $\begin{array}{l}{ }^{207} \mathrm{~Pb} / \\
{ }^{206} \mathrm{~Pb}\end{array}$ & \pm & & $\begin{array}{l}{ }^{206} \mathrm{~Pb} / \\
{ }^{238} \mathrm{U}\end{array}$ & \pm & $\begin{array}{l}{ }^{207} \mathrm{~Pb} / \\
{ }^{206} \mathrm{~Pb}\end{array}$ & \pm & \\
\hline 1.1 & 77 & 47 & 0.62 & 26.9 & 0.17 & 0.406 & 2.1 & 7.20 & 2.3 & 0.129 & 0.94 & 0.914 & 2197 & 39 & 2079 & 16 & -6 \\
\hline 2.1 & 66 & 44 & 0.70 & 23.1 & 0.09 & 0.409 & 2.3 & 7.56 & 2.6 & 0.134 & 1.3 & 0.858 & 2211 & 42 & 2150 & 24 & -3 \\
\hline 3.1 & 121 & 130 & 1.11 & 39 & 0.12 & 0.375 & 2.1 & 6.70 & 2.4 & 0.130 & 1.1 & 0.893 & 2052 & 38 & 2093 & 19 & 2 \\
\hline 4.1 & 129 & 77 & 0.62 & 38.2 & 0.31 & 0.345 & 2.2 & 5.28 & 2.6 & 0.111 & 1.3 & 0.864 & 1909 & 37 & 1817 & 23 & -5 \\
\hline 5.1 & 180 & 129 & 0.74 & 50.9 & 0.12 & 0.328 & 2.1 & 4.93 & 2.3 & 0.109 & 1.0 & 0.897 & 1829 & 33 & 1784 & 19 & -2 \\
\hline 6.1 & 149 & 40 & 0.28 & 33.8 & 0.05 & 0.265 & 2.1 & 3.49 & 2.5 & 0.096 & 1.3 & 0.853 & 1513 & 29 & 1541 & 24 & 2 \\
\hline 7.1 & 115 & 68 & 0.61 & 20.9 & 0.20 & 0.210 & 2.2 & 2.30 & 3.1 & 0.079 & 2.2 & 0.711 & 1231 & 24 & 1183 & 43 & -4 \\
\hline 8.1 & 162 & 94 & 0.60 & 28.3 & 0.20 & 0.203 & 2.1 & 2.19 & 2.8 & 0.078 & 1.8 & 0.756 & 1190 & 23 & 1151 & 37 & -3 \\
\hline 9.1 & 144 & 90 & 0.65 & 41.5 & 0.14 & 0.336 & 2.1 & 5.28 & 2.4 & 0.114 & 1.1 & 0.881 & 1866 & 34 & 1866 & 21 & 0 \\
\hline 10.1 & 183 & 222 & 1.25 & 49.3 & 0.32 & 0.313 & 2.2 & 5.53 & 2.4 & 0.128 & 1.1 & 0.892 & 1755 & 33 & 2072 & 19 & 15 \\
\hline 11.1 & 169 & 178 & 1.09 & 33.7 & 0.14 & 0.232 & 2.2 & 2.81 & 2.7 & 0.088 & 1.6 & 0.806 & 1347 & 27 & 1376 & 31 & 2 \\
\hline 12.1 & 52 & 64 & 1.26 & 17.5 & 0.15 & 0.389 & 2.3 & 7.12 & 2.8 & 0.133 & 1.6 & 0.832 & 2116 & 42 & 2136 & 27 & 1 \\
\hline 13.1 & 101 & 35 & 0.36 & 35.7 & 0.24 & 0.409 & 2.2 & 7.77 & 2.5 & 0.138 & 1.2 & 0.879 & 2211 & 41 & 2198 & 20 & -1 \\
\hline 14.1 & 341 & 302 & 0.92 & 105 & 0.85 & 0.356 & 2.0 & 7.67 & 2.3 & 0.156 & 1.2 & 0.870 & 1962 & 35 & 2417 & 20 & 19 \\
\hline 15.1 & 99 & 172 & 1.80 & 32.7 & 0.15 & 0.385 & 2.2 & 6.83 & 2.5 & 0.129 & 1.2 & 0.872 & 2101 & 39 & 2078 & 22 & -1 \\
\hline 16.1 & 125 & 95 & 0.78 & 37.6 & 0.34 & 0.348 & 2.1 & 5.84 & 2.5 & 0.122 & 1.3 & 0.862 & 1925 & 36 & 1982 & 22 & 3 \\
\hline 17.1 & 46 & 61 & 1.39 & 15 & 0.26 & 0.382 & 2.4 & 7.08 & 2.9 & 0.134 & 1.6 & 0.823 & 2087 & 42 & 2155 & 29 & 3 \\
\hline 18.1 & 72 & 74 & 1.07 & 21.1 & 0.32 & 0.340 & 2.4 & 5.34 & 2.9 & 0.114 & 1.6 & 0.829 & 1887 & 39 & 1863 & 29 & -1 \\
\hline 19.1 & 129 & 84 & 0.67 & 38.2 & 0.04 & 0.344 & 2.1 & 5.46 & 2.4 & 0.115 & 1.1 & 0.887 & 1905 & 35 & 1882 & 20 & -1 \\
\hline 20.1 & 60 & 36 & 0.62 & 22 & 0.27 & 0.423 & 2.3 & 7.93 & 2.8 & 0.136 & 1.6 & 0.826 & 2274 & 44 & 2176 & 27 & -4 \\
\hline 21.1 & 82 & 79 & 1.00 & 29.7 & 0.17 & 0.423 & 2.3 & 7.62 & 2.6 & 0.131 & 1.2 & 0.882 & 2272 & 44 & 2108 & 22 & -8 \\
\hline
\end{tabular}

Notes: Errors are 1-sigma; $\mathrm{Pbc}$ and $\mathrm{Pb}^{*}$ indicate the common and radiogenic portions, respectively.

Error in Standard calibration was $0.50 \%$ (not included in above errors but required when comparing data from different mounts).

(1) Common $\mathrm{Pb}$ corrected using measured ${ }^{204} \mathrm{~Pb} /{ }^{206} \mathrm{~Pb}$ ratio.

detailed sedimentological study has established a disconformity just where the $\delta^{13} \mathrm{C}$ data increase to positive values (Vieira et al., 2007a, b). In addition, seismic data also support this disconformity at the lower part of the Sete Lagoas Formation (Zalán and Romeiro-Silva, 2007), indicating that the Carrancas and Jequitaí diamictites together with the $c .740 \mathrm{Ma}$ cap carbonate would be an older succession compared to the rest of the Bambuí Group which is younger than $610 \mathrm{Ma}$ (Rodrigues, 2008).

\section{Conclusions}

The $\mathrm{U}-\mathrm{Pb}$ and $\mathrm{Sm}-\mathrm{Nd}$ results presented here were interpreted in terms of the joint evolution of the Macaúbas and West Congolian basins (Fig. 8). This evolution should be envisaged in the scenario of a mantle-activated asymmetric rift, in which the magma-rich zone was inherited by the West Congo belt after the opening of the South Atlantic Ocean. This rift evolved to a confined basin partially floored

Table 6

U-Pb SHRIMP data from detrital zircons of sample MG05-03 (Lower Chapada Acauã Formation).

\begin{tabular}{|c|c|c|c|c|c|c|c|c|c|c|c|c|c|c|c|c|c|}
\hline \multirow{2}{*}{$\begin{array}{l}\text { Grain. } \\
\text { spot }\end{array}$} & \multirow{2}{*}{$\begin{array}{l}\mathrm{U} \\
(\mathrm{ppm})\end{array}$} & \multirow{2}{*}{$\begin{array}{l}\text { Th } \\
\text { (ppm) }\end{array}$} & \multirow{2}{*}{$\begin{array}{l}{ }^{232} \mathrm{Th} \\
{ }^{238} \mathrm{U}\end{array}$} & \multirow{2}{*}{$\begin{array}{l}{ }^{206} \mathrm{~Pb}^{*} \\
\text { (ppm) }\end{array}$} & \multirow{2}{*}{$\begin{array}{l}{ }^{206} \mathrm{Pbc} \\
\%\end{array}$} & \multicolumn{6}{|c|}{ Radiogenic ratios } & \multirow[b]{2}{*}{$\rho$} & \multicolumn{4}{|c|}{ Age (Ma) } & \multirow{2}{*}{$\begin{array}{l}\% \\
\text { Disc. }\end{array}$} \\
\hline & & & & & & $\begin{array}{l}{ }^{206} \mathrm{~Pb} / \\
{ }^{238} \mathrm{U}\end{array}$ & $\pm \%$ & $\begin{array}{l}{ }^{207} \mathrm{~Pb} / \\
{ }^{235} \mathrm{U}\end{array}$ & $\pm \%$ & $\begin{array}{l}{ }^{207} \mathrm{~Pb} / \\
{ }^{206} \mathrm{~Pb}\end{array}$ & \pm & & $\begin{array}{l}{ }^{206} \mathrm{~Pb} / \\
{ }^{238} \mathrm{U}\end{array}$ & \pm & $\begin{array}{l}{ }^{207} \mathrm{~Pb} / \\
{ }^{206} \mathrm{~Pb}\end{array}$ & \pm & \\
\hline 1.1 & 83 & 44 & 0.55 & 27.9 & 0.21 & 0.391 & 1.5 & 6.810 & 2.2 & 0.127 & 1.5 & 0.706 & 2126 & 28 & 2049 & 27 & -4 \\
\hline 2.1 & 93 & 47 & 0.53 & 32.5 & 0.15 & 0.405 & 1.6 & 7.430 & 2 & 0.133 & 1.1 & 0.829 & 2194 & 30 & 2137 & 19 & -3 \\
\hline 3.1 & 94 & 78 & 0.85 & 31.5 & 0.35 & 0.388 & 1.8 & 6.870 & 2.2 & 0.129 & 1.3 & 0.816 & 2114 & 32 & 2077 & 22 & -2 \\
\hline 4.1 & 103 & 90 & 0.90 & 31.1 & 0.38 & 0.351 & 1.8 & 5.290 & 2.5 & 0.110 & 1.7 & 0.715 & 1937 & 30 & 1791 & 31 & -8 \\
\hline 5.1 & 94 & 53 & 0.58 & 34.6 & 0.19 & 0.428 & 1.8 & 7.770 & 2.1 & 0.132 & 1.2 & 0.838 & 2296 & 35 & 2121 & 20 & -8 \\
\hline 6.1 & 160 & 65 & 0.42 & 46.6 & 0.26 & 0.338 & 1.5 & 4.869 & 1.9 & 0.105 & 1.1 & 0.805 & 1876 & 25 & 1707 & 21 & -10 \\
\hline 7.1 & 260 & 79 & 0.31 & 47.9 & 0.21 & 0.214 & 1.5 & 2.384 & 2 & 0.081 & 1.4 & 0.737 & 1249 & 17 & 1219 & 27 & -3 \\
\hline 8.1 & 241 & 315 & 1.35 & 66 & 2.88 & 0.310 & 1.6 & 5.470 & 3.9 & 0.128 & 3.6 & 0.401 & 1739 & 24 & 2073 & 63 & 16 \\
\hline 9.1 & 57 & 27 & 0.48 & 26 & 0.25 & 0.529 & 1.8 & 13.500 & 2.1 & 0.185 & 1.1 & 0.852 & 2738 & 39 & 2698 & 18 & -1 \\
\hline 10.1 & 88 & 78 & 0.92 & 30.6 & 0.23 & 0.402 & 1.8 & 7.430 & 2.1 & 0.134 & 1.2 & 0.838 & 2180 & 33 & 2151 & 20 & -1 \\
\hline 11.1 & 22 & 23 & 1.05 & 3.12 & 1.64 & 0.160 & 2.5 & 1.760 & 10 & 0.079 & 9.7 & 0.254 & 959 & 23 & 1183 & 190 & 19 \\
\hline 11.2 & 59 & 62 & 1.10 & 9.19 & 0.94 & 0.180 & 1.9 & 1.764 & 5.1 & 0.071 & 4.7 & 0.373 & 1067 & 19 & 959 & 97 & -11 \\
\hline 12.1 & 43 & 39 & 0.94 & 14.5 & 0.61 & 0.388 & 1.9 & 6.740 & 2.9 & 0.126 & 2.2 & 0.656 & 2114 & 34 & 2043 & 39 & -3 \\
\hline 13.1 & 48 & 12 & 0.25 & 16.8 & 0.47 & 0.403 & 2.1 & 7.180 & 2.8 & 0.129 & 1.9 & 0.735 & 2182 & 38 & 2089 & 33 & -4 \\
\hline 14.1 & 67 & 65 & 1.00 & 18.4 & 0.51 & 0.319 & 1.8 & 4.560 & 3.1 & 0.104 & 2.6 & 0.563 & 1787 & 27 & 1691 & 47 & -6 \\
\hline 15.1 & 126 & 74 & 0.60 & 42 & 0.18 & 0.388 & 1.6 & 7.280 & 1.9 & 0.136 & 10 & 0.845 & 2115 & 28 & 2177 & 17 & 3 \\
\hline 16.1 & 136 & 59 & 0.44 & 64.6 & 0.06 & 0.552 & 1.6 & 14.510 & 1.7 & 0.191 & 0.67 & 0.919 & 2833 & 36 & 2748 & 11 & -3 \\
\hline 17.1 & 144 & 61 & 0.43 & 56.7 & 0.11 & 0.457 & 1.5 & 9.920 & 1.9 & 0.158 & 1 & 0.832 & 2425 & 31 & 2429 & 17 & 0 \\
\hline 18.1 & 162 & 224 & 1.43 & 51.2 & 0.11 & 0.367 & 1.5 & 6.180 & 1.8 & 0.122 & 0.89 & 0.864 & 2015 & 27 & 1987 & 16 & -1 \\
\hline 19.1 & 216 & 100 & 0.48 & 53.4 & 0.34 & 0.286 & 1.5 & 4.053 & 1.9 & 0.103 & 1.1 & 0.805 & 1623 & 22 & 1673 & 20 & 3 \\
\hline 20.1 & 210 & 200 & 0.99 & 59.3 & 0.10 & 0.329 & 1.6 & 5.199 & 1.8 & 0.115 & 0.92 & 0.863 & 1834 & 25 & 1873 & 17 & 2 \\
\hline 21.1 & 198 & 234 & 1.22 & 45 & 0.13 & 0.264 & 1.5 & 3.312 & 1.9 & 0.091 & 1.1 & 0.797 & 1512 & 20 & 1444 & 22 & -5 \\
\hline 22.1 & 157 & 147 & 0.96 & 32 & 0.19 & 0.236 & 1.6 & 2.764 & 2.1 & 0.085 & 1.4 & 0.738 & 1367 & 19 & 1314 & 27 & -4 \\
\hline 23.1 & 243 & 83 & 0.35 & 53.9 & 0.15 & 0.258 & 1.5 & 3.188 & 1.8 & 0.090 & 1.1 & 0.814 & 1477 & 20 & 1421 & 20 & -4 \\
\hline
\end{tabular}

Notes: Errors are 1-sigma; $\mathrm{Pbc}$ and $\mathrm{Pb}^{*}$ indicate the common and radiogenic portions, respectively.

Error in Standard calibration was $0.63 \%$ (not included in above errors).

(1) Common $\mathrm{Pb}$ corrected using measured ${ }^{204} \mathrm{~Pb} /{ }^{206} \mathrm{~Pb}$ ratio. 


\section{SOUTHERN SÃO FRANCISCO CRATON}

\section{ARAÇUAI OROGEN}

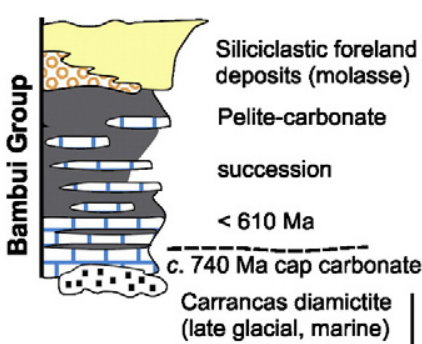

Early Cryogenian

glacial event

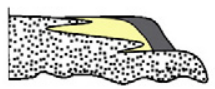

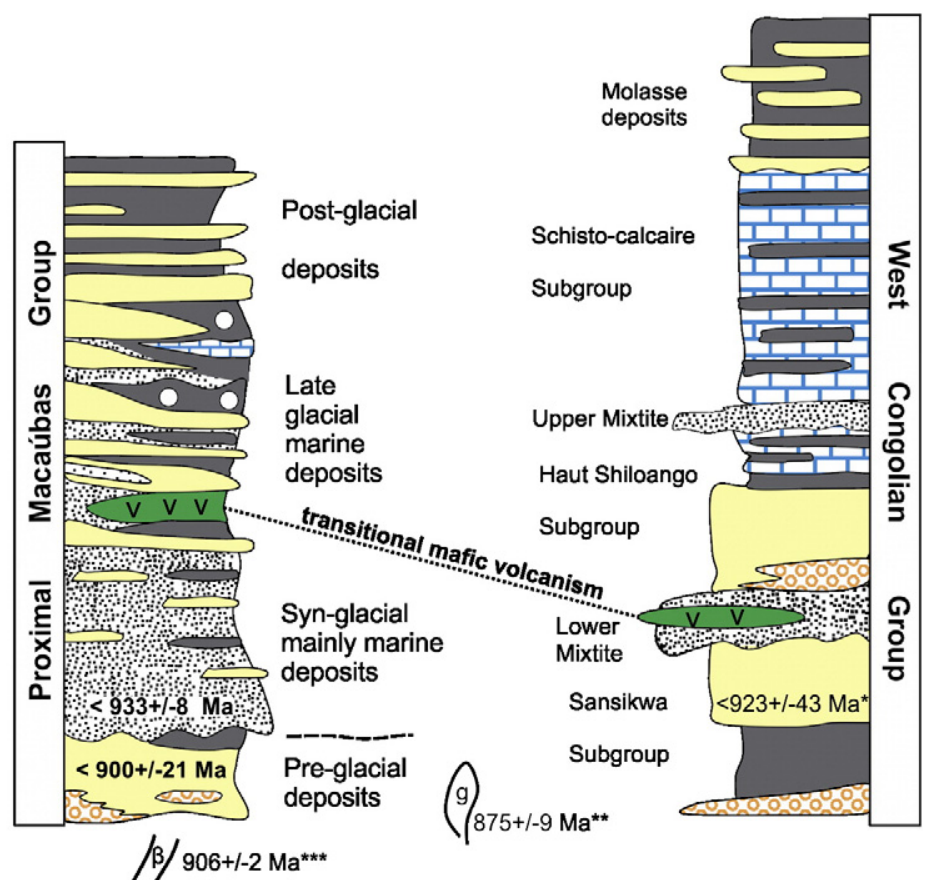
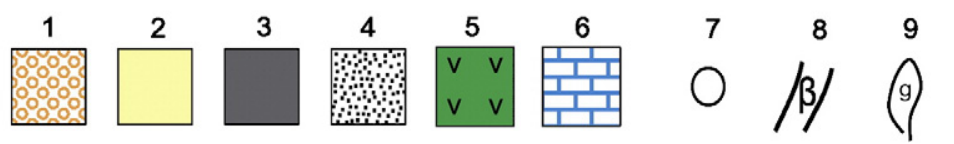

10

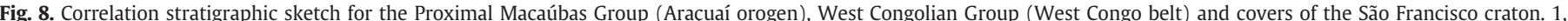

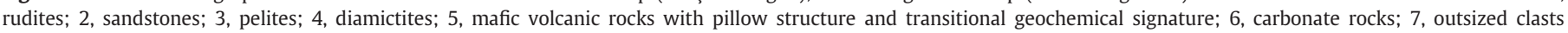

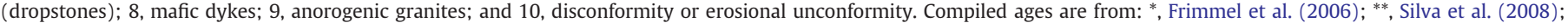
*** Machado et al. (1989).

by oceanic crust (Alkmim et al., 2006; Pedrosa-Soares et al. 2001, 2008).

The basin began to open in the Stenian-Tonian boundary, when it started to be filled by the thick Zadinian-Mayumbian volcanosedimentary succession (1000-900 Ma), that together with the related intrusions represent the thermal-magmatic axis of the asymmetric rift. No correlative of the Zadinian and Mayumbian groups is known in the Araçuaí orogen. However, the presence of the $c$. 875 Ma A-type granites in the northeast tip of this orogen suggests that the thermal axis of the rift migrated to the west (in relation to the present-day geography) in the Late Tonian (Silva et al., 2008), so that the basin widening shifted to the Brazilian side. At that time, after 900 Ma ago, deposition of the lower diamictite-free sedimentary succession of the Macaúbas basin began, probably coeval with the Sansikwa Subgroup of the West Congolian basin. At least part of the Macaúbas pre-glacial deposits are interpreted to be contemporaneous with the magmatic episode that generated the $c$. 875 Ma granites (Fig. 8).

After this Late Tonian sedimentation, a climatic change to glacial conditions affected the São Francisco-Congo continent and neighboring basins, so that a huge amount of diamictites started to fill the Macaúbas basin. The correlations between the Macaúbas diamictites and those covered by the $c$. $740 \mathrm{Ma}$ cap carbonate on the São Francisco craton suggest that this climatic change can be correlated to the Early Cryogenian (known as Old Cryogenian) glacial event. The Serra do Catuni Formation is considered to be an equivalent of the Jequitaí diamictite, depicting a lateral succession of glacial environments from glacio-terrestrial, on the São Francisco craton, to proximal glacio-marine along the western region of the Macaúbas basin. The transitional mafic volcanism of the Lower Chapada Acauã Formation signals the end of the continental rift stage, which seems to be coeval with a climatic change to non-glacial conditions indicated by the absence of diamictites in the upper units of the Chapada Acauã Formation. This implies that at least part of the Chapada Acauã diamictites record the deglaciation process in the region. The Chapada Acauã diamictite succession is considered to be equivalent to the Carrancas diamictite, placed on the southern São Francisco craton, and to the Lower Mixtite Formation of the West Congo belt (Fig. 8). The Upper Mixtite Formation of the West Congo belt would have no equivalent in the Macaúbas basin, and might represent a local glaciation in the African side, coeval or younger than the upper part of the pelite-carbonate cover of the São Francisco craton, which maximum age is c. 590 Ma.

The continental rift to passive margin transition is related to the generation of oceanic crust in the distal Macaúbas basin, where the Ribeirão da Folha Formation was deposited (Figs. 2 and 3). The U-Pb dating of zircon crystals from plagiogranites of an ophiolite hosted by the Ribeirão da Folha Formation resulted in an age around $660 \mathrm{Ma}$ (Queiroga et al., 2007). Considering that both the diamictite-free Ribeirão da Folha and Upper Chapada Acauã formations are lateral equivalents, the age of the ophiolite provides further evidence that the Macaúbas diamictites might record a glaciation older than $660 \mathrm{Ma}$. In fact, the deglaciation process can explain the rise of the sea level followed by the deposition of the $c$. $740 \mathrm{Ma}$ cap carbonates over diamictites on the São Francisco craton, and the diamictite-free Upper Chapada Acauã Formation can be considered a correlative of the lower part of the pelite-carbonate cratonic cover. 


\section{Acknowledgments}

The authors acknowledge financial support provided by FAPESP (Fundação de Amparo à Pesquisa do Estado de São Paulo), CNPq (Conselho Nacional de Desenvolvimento Científico e Tecnológico), FINEP (Financiadora de Estudos e Projetos), and FAPEMIG (Fundação de Amparo à Pesquisa de Minas Gerais). Fernando Alkmim is thanked for showing us some of the outcrops studied here. Alan Collins kindly reviewed a previous version of the manuscript. Constructive reviews by Daniel Le Heron and Stephen Marshak contribute to improve the original manuscript. We dedicate this work to our beloved friend and coauthor - the late Carlos Maurício Noce - who contributed significantly for the understanding of the São Francisco Craton and Araçuaí Fold Belt evolution.

\section{References}

Alkmim, F.F., Marshak, S., Pedrosa-Soares, A.C., Peres, G.G., Cruz, S.C., Whittington, A., 2006. Kinematic evolution of the Araçuaí-West Congo orogen in Brazil and Africa: nutcracker tectonics during the Neoproterozoic assembly of Gondwana. Precambrian Research 149, 43-63.

Babinski, M., Van Schmus, W.R., Chemale Jr., F., Brito Neves, B.B., Rocha, A.J.D., 1993. Idade isocrônica $\mathrm{Pb} / \mathrm{Pb}$ em rochas carbonáticas da Formação Caboclo, em Morro do Chapéu, BA. Simpósio sobre o Cráton do São Francisco, 2. Anais, Salvador, BA, Brazil, pp. $160-163$.

Babinski, M., Brito Neves, B.B., Machado, N., Noce, C.M., Uhlein, A., Van Schmus, W.R., 1994 Problemas da metodologia U/Pb de vulcânicas continentais: Caso do Grupo dos Remédios, Supergrupo Espinhaço no Estado da Bahia. Congresso Brasileiro de Geologia, 38, 2. Resumos Expandidos, Balneário de Camboriú, SC., Brazil, pp. 409-410.

Babinski, M., Van Schmus, W.R., Chemale, F., 1999. Pb-Pb dating and Pb isotope geochemistry of Neoproterozoic carbonate rocks from the São Francisco basin, Brazil: implications for the mobility of $\mathrm{Pb}$ isotopes during tectonism and metamorphism. Chemical Geology 160, 175-199.

Babinski, M., Gradim, R.., Pedrosa-Soares, A.C., Alkmim, F.F., Noce, C.M., Liu, D., 2005. Geocronologia U-Pb (SHRIMP) e Sm-Nd de xistos verdes basálticos do Orógeno Araçuaí: Implicações para a idade do Grupo Macaúbas. Revista Brasileira de Geociências 4-supplement, 77-81.

Babinski, M., Vieira, L.C., Trindade, R.I.F., 2007. Direct dating of the Sete Lagoas cap carbonate (Bambuí Group, Brazil) and implications for the Neoproterozoic glacial events. Terra Nova 19, 401-406.

Battilani, G.A., Vasconcelos, P.M., Gomes, N.S., Guerra, W.J., 2005. Geochronological data of dykes and sills intruding Proterozoic sequences of the Tombador Formation, Bahia - Brazil. Simpósio do Cráton do São Francisco, 3, 1. Short Papers, Salvador, Bahia, Brazil, pp. 139-142.

Batumike, J.M., Griffin, W.L., O'Reilly, S.Y., Belousova, E.A., Pawlirschek, M., 2009. Crustal evolution in the central Congo-Kasai Craton, Luebo, D.R.Congo: insights from zircon U-Pb ages, Hf-isotope and trace-element data. Precambrian Research 170, 107-115.

Black, L.P., Kamo, S.L., Allen, C.M., Aleinikoff, J.N., Davis, D.W., Korsch, R.J., Foudoulis, C., 2003. TEMORA 1: a new zircon standard for Phanerozoic $\mathrm{U}-\mathrm{Pb}$ geochronology. Chemical Geology 200, 155-170.

Bowring, S., Myrow, P., Landing, E., Ramezani, J., Grotzinger, J., 2003. Geochronological constraints on terminal Neoproterozoic events and the rise of metazoans. Geophysical Research Abstracts 5, 13219.

Brito Neves, B.B., Kawashita, K., Cordani, U.G., Delhal, J., 1979. A evolução geocronológica da Cordilheira do Espinhaço; dados novos e integração. Revista Brasileira de Geociências 9, 71-85.

Buchwaldt, R., Toulkeridis, T., Babinski, M., Santos, R., Noce, C.M., Martins-Neto, M.A., Hercos, C.M., 1999. Age determination and age-related provenance analysis of the Proterozoic glaciation event in central-eastern Brazil. South American Symposium on Isotope Geology, 2. Actas, Cordoba, Argentina, pp. 387-390.

Chemale Jr., F., Dussin, I.A., Martins, M., Alkmim, F.F., Queiroga G., 2010. The Espinhaço Supergroup in Minas Gerais: a Stenian Basin? In: South American Symposium on Isotope Geology, 7, Brasília, Brazil. Short Papers, CD-ROM, 4 p.

Chumakov, N.M., Elston, D.P., 1989. The paradox of Late Proterozoic glaciations at low latitudes. Episodes 12, 115-120.

Collins, A.S., Pisarevsky, S.A., 2005. Amalgamating Eastern Gondwana: the evolution of the Circum-Indian orogens. Earth-Science Reviews 71, 229-270.

Cordani, U.G., D'Agrella Filho, M.S., Brito Neves, B.B., Trindade, R.I.F., 2003. Tearing up Rodinia: the Neoproterozoic palaeogeography of South American cratonic fragments. Terra Nova 15, 350-359.

Cox, R., Coleman, D.S., Chokel, C.B., DeOreo, S.B., Wooden, J., Collins, A.S., De Waele, B., Kröner, A., 2004. Proterozoic tectonostratigraphy and paleogeography of Central Madagascar derived from detrital zircons U-Pb age populations. Journal of Geology 112, 379-399.

D'Agrella Filho, M.S., Pacca, I.I.G., Trindade, R.I.F., Teixeira, W., Raposo, M.I.B., Onstott, T.C., 1990. Paleomagnetism of Middle Proterozoic (1.01 to $1.08 \mathrm{Ga}$ ) mafic dykes in southeastern Bahia State- São Francisco craton, Brazil. Earth and Planetary Science Letters $101,332-348$.

Danderfer, A., De Waele, B., Pedreira, A.J., Nalini, H.A., 2009. New geochronological constraints on the geological evolution of Espinhaço basin within the São Francisco Craton - Brazil. Precambrian Research 170, 116-128.
De Paepe, P., Hertogen, J., Tack, L., 1975. Mise en évidence de laves en cousins dans les faciès volcaniques basiques du massif de Kimbungu (Bas-Zaire) et implications pour le magmatisme ouest-congolien. Annales Société Geologique Belgique 98, 251-270.

de Sá, Jardim, E.F., McReath, I., Brito Neves, B.B., Bartels, R.L., 1976. Novos dados geocronológicos sobre o Cráton do São Francisco no Estado da Bahia. Congresso Brasileiro de Geologia, 29. Anais, Belo Horizonte, Brazil, pp. 185-204.

De Waele, B., Kampunzu, A.B., Mapani, B.S.E., Tembo, F., 2006. The Mesoproterozoic Irumide belt of Zambia. Journal of African Earth Sciences 46, 36-70.

DePaolo, D.J., 1981. A neodymium and strontium isotopic study of the Mesozoic calcalkaline granitic batholiths of the Sierra Nevada and Peninsular Ranges, California. Journal of Geophysical Research 86, 10470-10488.

Evans, D.M., Windrim, D.P., Armstrong, R.A., 2007. Age of metavolcanic rocks at the northern margin of the Namaqua-Natal Metamorphic Province in the Karas Mountains, Namibia, defined by SHRIMP U-Pb dating of zircons. South African Journal of Geology 110, 47-54.

Figueiredo, F.T., Almeida, R.P., Tohver, E., Babinski, M., Liu, D., Fanning, C.M., 2009 Neoproterozoic glacial dynamics revealed by provenance of diamictites of the Bebedouro Formation, São Francisco Craton, Central Eastern Brazil. Terra Nova 21, 375-385.

Frimmel, H.E., Folling, P.G., Eriksson, P., 2002. Neoproterozoic tectonic and climatic evolution recorded in the Gariep Belt, Namibia and South Africa. Basin Research 14, 55-67.

Frimmel, H.E., Tack, L., Basei, M., Nutman, A., Boven, A., 2006. Provenance and chemostratigraphy of the Neoproterozoic West Congolian Group in the Democratic Republic of Congo. Journal of African Earth Sciences 46, 221-239.

Gradim, R.J., Alkmim, F.F., Pedrosa-Soares, A.C., Babinski, M., Noce, C.M., 2005. Xistos Verdes do Alto Araçuaí, Minas Gerais: Vulcanismo Básico do Rifte Neoproterozóico Macaúbas. Revista Brasileira de Geociências 35 (4-suplemento), 59-69.

Gravenor, C.P., Monteiro, R., 1983. Ice-thrust features in the Proterozoic Macaúbas Group, Jequitaí area, Minas Gerais, Brazil. Journal of Geology 91, 113-116.

Grossi-Sad, J.H., Lobato, L.M., Pedrosa-Soares, A.C., Soares-Filho, B.S., 1997. Projeto Espinhaço. CODEMIG, Belo Horizonte.

Guimarães, J.T., Teixeira, L.R., Silva, M.G., Martins, A.A.M., Filho, E.L.A., Loureiro, H.S.C., Arcanjo, J.B., Souza, J.D., Neves, J.P., Mascarenhas, J.F., Melo, R.C., Bento, R.V., 2005 Datações U-Pb em rochas magmáticas intrusivas no Complexo Paramirim e no Rifte Espinhaço: uma contribuição ao estudo da evolução geocronológica da Chapada Diamantina. Simpósio sobre o Cráton do São Francisco, 3. Short Papers, Salvador, Brazil, pp. 159-161.

Hettich, M., Karfunkel, J., 1978. Um esker, um varvito e seixos estriados no Grupo Macaúbas, norte de Minas Gerais. Revista Escola de Minas de Ouro Preto 34, 5-8.

Hoffman, P.F., 2009. Pan-glacial - a third state in the climate system. Geology Today 25, $107-114$.

Hoffman, P.F., Li, Z., 2009. A palaeogeographic context for neoproterozoic glaciation. Palaeogeography, Palaeoclimatology, Palaeoecology 277, 158-172.

Isotta, C.A.L., Rocha-Campos, A.C., Yoshida, R., 1969. Striated pavement of the Upper Precambrian glaciation in Brazil. Nature 222, 466-468.

Kampunzu, A.B., Kapenda, D., Manteka, B., 1991. Basic magmatism and geotectonic evolution of the Pan African belt in central Africa: evidence from the Katangan and West Congolina segments. Tectonophysics 190, 363-371.

Karfunkel, J., Hoppe, A., 1988. Late Precambrian glaciation in central-eastern Brazil: synthesis and model. Palaeogeography, Palaeoclimatology, Palaeoecology 65, 1-21.

Karfunkel, J., Hoppe, A., Noce, C.M., 2002. Serra da Água Fria e vizinhanças, MG: vestígios de glaciação neoproterozóica. In: Schobbenhaus, C., Campos, D.A., Queiroz, E.T., Winge, M., Berbert-Born, M. (Eds.), Sítios Geológicos e Paleontológicos do Brasil, 1. DNPM, Brasília, Brazil, pp. 165-173.

Klein, P.B.W., 2008. Geoquímica de rocha total, geocronologia U-Pb e geologia isotópica de Sm-Nd das rochas ortognáissicas e unidades litológicas associadas da região Ipameri - Catalão (Goiás). Unpublished PhD Dissertation, University of Brasília Brasília, Brazil.

Kuchenbecker, M., Babinski, M., Pedrosa-Soares, A.C., Lopes-Silva, L., Pimenta, F., Rossi, M.G., Dias, P.H.A., 2010. Isotopic approach of the basement/cover boundary in Arcos region (Brazil): new evidence of a Neoproterozoic glaciation in the São Francisco basin. South American Symposium on Isotope Geology, 7. Short Papers, Brasília, Brazil. CD-ROM.

Ludwig, K.R., 2001. User's manual for Isoplot/Ex Version 2.49 A geochronological toolkit for Microsoft Excel. Berkeley Geochronological Center, Special Publication 1a, 55.

Macedo, M.H.F., Bonhomme, M.G., 1984. Contribuição à cronoestratigrafia das formações Caboclo, Bebedouro e Salitre na Chapada Diamantina (BA) pelos métodos Rb-Sr e K-Ar. Revista Brasileira de Geociências 14, 153-163.

Machado, N., Schrank, A., Abreu, F.R., Knauer, L.G., Almeida-Abreu, P.A., 1989. Resultados preliminares da geocronologia U-Pb na Serra do Espinhaço Meridional. Boletim do Núcleo Minas Gerais-Sociedade Brasileira de Geologia 10, 171-174.

Martins, M.S., 2006. Geologia dos diamantes e carbonados aluvionares da bacia do Rio Macaúbas, MG. Unpublished PhD dissertation, Instituto de Geociências, Universidade Federal de Minas Gerais, Belo Horizonte, Brazil.

Martins, M., Karfunkel, J., Noce, C.M., Babinski, M., Pedrosa-Soares, A.C., Sial, A.N., Liu, D. 2008. A sequência pré-glacial do Grupo Macaúbas na área-tipo e o registro da abertura do rifte Araçuaí. Revista Brasileira de Geociências 38, 768-779.

Martins-Neto, M.A., Hercos, C.M., 2002. Sedimentation and tectonic setting of Early Neoproterozoic glacial deposits in southeastern Brazil. In: Altermann, W., Corcoran, P.L. (Eds.), Precambrian Sedimentary Environments: A Modern Approach to Ancient Depositional Systems., 33. International Association of Sedimentologists, pp. 383-403. Special Publications.

Martins-Neto, M.A., Gomes, N.S., Hercos, C.M., Reis, L.A., 1999. Fácies gláciocontinentais (outwash plain) na Megasseqüência Macaúbas (Serra da Água Fria MG) e seu contexto geotectônico. Revista Brasileira de Geociências 29, 179-188.

Martins-Neto, M.A., Pedrosa-Soares, A.C., Lima, S.A.A., 2001. Tectono-sedimentary evolution of sedimentary basins from Late Paleoproterozoic to Late Neoproterozoic 
in the São Francisco craton and Araçuaí fold belt, eastern Brazil. Sedimentary Geology 141 (142), 343-370.

Montes, A.S.L., Gravenor, C.P., Montes, M.L., 1985. Glacial sedimentation in the Late Precambrian Bebedouro Formation, Bahia, Brazil. Sedimentary Geology 44, 349-358.

Moraes, L.J., Guimarães, D., 1931. The diamond-bearing region of Northern Minas Gerais, Brazil. Economic Geology 26, 502-530.

Noce, C.M., 1997. Geologia da Folha Curimataí. In: Grossi-Sad, J.H., Lobato, L.M., Pedrosa-Soares, A.C., Soares-Filho, B.S. (Eds.), Projeto Espinhaço. CODEMIG, Belo Horizonte, pp. 1207-1250.

Noce, C.M., Pedrosa-Soares, A.C., Grossi-Sad, J.H., Baars, F.J., Guimarães, M.V., Mourão, M.A.A., Oliveira, M.J.R., Roque, N.C., 1997. Nova subdivisão estratigráfica regional do Grupo Macaúbas na Faixa Araçuaí: o registro de uma bacia neoproterozóica. Boletim do Núcleo Minas Gerais-Sociedade Brasileira de Geologia 14, 29-31.

Pedrosa-Soares, A.C., Oliveira, M.J.R., 1997. Geologia da Folha Salinas. In: Grossi-Sad, J.H., Lobato, L.M., Pedrosa-Soares, A.C., Soares-Filho, B.S. (Eds.), Projeto Espinhaço. CODEMIG, Belo Horizonte, pp. 419-541.

Pedrosa-Soares, A.C., Noce, C.M., Vidal, P., Monteiro, R., Leonardos, O.H., 1992. Toward new tectonic model for the Late Proterozoic Araçuí (SE Brazil) - West Congolian (SW Africa) Belt. Journal of South American Earth Sciences 6, 33-47.

Pedrosa-Soares, A.C., Vidal, P., Leonardos, O.H., Brito-Neves, B.B., 1998. Neoproterozoic oceanic remnants in eastern Brazil: further evidence and refutation of an exclusively ensialic evolution for the Araçuaí-West Congo orogen. Geology 26, 519-522.

Pedrosa-Soares, A.C., Noce, C.M., Wiedemann, C.M., Pinto, C.P., 2001. The Araçuaí-West Congo orogen in Brazil: an overview of a confined orogen formed during Gondwanland assembly. Precambrian Research 110, 307-323.

Pedrosa-Soares, A.C., Noce, C.M., Alkmim, F.F., Silva, L.C., Babinski, M., Cordani, U. Castañeda, C., 2007. Orógeno Araçuaí: síntese do conhecimento 30 anos após Almeida 1977. Geonomos 15, 1-16 (http://www.igc.ufmg.br/geonomos/PDFs/ 15_1_1_16_Pedrosa.pdf).

Pedrosa-Soares, A.C., Alkmim, F.F., Tack, L., Noce, C.M., Babinski, M., Silva, L.C., MartinsNeto, M.A., 2008. Similarities and differences between the Brazilian and African counterparts of the Neoproterozoic Araçuaí-West Congo orogen. In: Pankhurst, R.J., Trouw, R.A.J., Brito Neves, B.B., de Wit, M.J. (Eds.), West Gondwana: Pre-Cenozoic Correlations Across the South Atlantic Region., 294. Geological Society, London, pp. 153-172. Special Publications.

Pettersson, Å., Cornell, D.H., Moen, H.F.G., Reddy, S., Evans, D., 2007. Ion-probe dating of $1.2 \mathrm{Ga}$ collision and crustal architecture in the Namaqua-Natal Province of southern Africa. Precambrian Research 158, 79-92.

Porada, H., 1989. Pan-African rifting and orogenesis in southern to equatorial Africa and Eastern Brazil. Precambrian Research 44, 103-136.

Queiroga, G.N., Pedrosa-Soares, A.C., Noce, C.M., Alkmim, F.F., Pimentel, M.M., Dantas, E.,

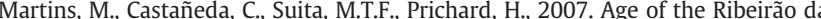
Folha ophiolite, Araçuaí Orogen: the U-Pb zircon dating of a plagiogranite. Geonomos 15, 61-65

Rocha-Campos, A.C., Hasui, Y., 1981. Tillites of the Macaúbas Group (Proterozoic) in central Minas Gerais and southern Bahia, Brazil. In: Hambrey, MJ, Harland, W.B. (Eds.) Earth's pre-Pleistocene Glacial Record. Cambridge University Press, pp. 933-939.

Rodrigues, J.B., 2008. Proveniência de sedimentos dos grupos Canastra, Ibiá, Vazante e Bambuí - Um estudo de zircões detríticos e idades-modelo Sm-Nd. Unpublished PhD Dissertation, Instituto de Geociências, Universidade de Brasília, Brazil.

Schobbenhaus, C., Hoppe, A., Baumann, A., Lork, A., 1994. Idade U/Pb do vulcanismo Rio dos Remédios, Chapada Diamantina, Bahia. Congresso Brasileiro de Geologia, 38, 2. Resumos Expandidos, Balneário de Camboriú, SC, Brazil, pp. 397-399.

Schöll, W.U., 1972. Der südwestliche Randbereich der Espinhaço Zone, Minas Gerais, Brasilien. Geologische Rundschau 61, 201-216.

Schrank, A., Dourado, B.V., Biondi, J.C., 1978. Estudo preliminar dos metavulcanitos do Grupo Macaúbas na região do Alto Jequitinhonha, MG. Congresso Brasileiro de Geologia 30, 3. Anais, Recife, Brazil, pp. 1323-1335.
Silva, L.C., Pedrosa-Soares, A.C., Teixeira, L.R., 2008. Tonian rift-related, A-type continental plutonism in the Araçuaí orogen, Eastern Brazil: new evidences for the breakup stage of the São Francisco-Congo Paleocontinent. Gondwana Research 13, 527-537.

Steiger, R.H., Jäger, E., 1977. Subcommission on geochronology: convention on the use of decay constants in geo- and cosmochronology. Earth and Planetary Science Letter 36, 359-362.

Tack, L., Liégeois, J.P., Deblond, A., Duchesne, J.C., 1994. Kibaran A-type granitoids and mafic rocks generated by two mantle sources in a late orogenic setting (Burundi). Precambrian Research 68, 323-356.

Tack, L., Wingate, M.T.D., Liégeois, J.P., Fernandez-Alonso, M., Deblond, A., 2001. Early Neoproterozoic magmatism (1000-910 Ma) of the Zadinian and Mayumbian Groups (Bas-Congo): onset of Rodinian rifting at the western edge of the Congo craton. Precambrian Research 110, 277-306.

Távola, F.I., Cordani, U.G., Kawashita, K., 1967. Determinações de idade potássio-argônio de rochas da região central da Bahia. Congresso Brasileiro de Geologia, 21. Anais, Curitiba, Brazil, pp. 214-224.

Trompette, R., 1994. Geology of western Gondwana (2000-500 Ma). Pan-African Brasiliano aggregation of South America and Africa. A.A.Balkema, Rotterdam. 350 p.

Tuller, M.P., 2009. Folha Sete Lagoas 1:100.000. Programa Geologia do Brasil, GEOBANK http://geobank.sa.cprm.gov.br.

Uhlein, A., Trompette, R., Egydio-Silva, M., 1998. Proterozoic rifting and closure, SE border of the São Francisco craton, Brazil. Journal of South American Earth Sciences 11, 191-203.

Uhlein, A., Trompette, R., Alvarenga, C., 1999. Neoproterozoic glacial and gravitational sedimentation on a continental rifted margin: the Jequitaí-Macaúbas sequence (Minas Gerais, Brazil). Journal of South American Earth Sciences 12, 435-451.

Uhlein, A., Trompette, R., Egydio-Silva, M., Vauchez, A., 2007. A glaciação Sturtiana ( $750 \mathrm{Ma})$, a estrutura do rifte Macaúbas-Santo Onofre e a estratigrafia do Grupo Macaúbas, Faixa Araçuaí. Geonomos 15, 45-60 (http://www.igc.ufmg.br/geonomos/ PDFs/15_1_45_60_Uhlein.pdf)

Valeriano, C.M., Machado, N., Simonetti, A., Valladares, C.S., Seer, H.J., Simões, L.S.A., 2004. U-Pb geochronology of the southern Brasilia belt (SE-Brazil): sedimentary provenance, Neoproterozoic orogeny and assembly of West Gondwana. Precambrian Research 130, 27-55.

Valladares, C.S., Machado, N., Heilbron, M., Gauthier, G., 2004. Ages of detrital zircon from siliciclastic successions south of the São Francisco Craton, Brazil: implication for the evolution of proterozoic basins. Gondwana Research 7, 913-921.

Vieira, L.C., Almeida, R.P., Trindade, R.I.F., Nogueira, A.C.R., Janikian, L., 2007a. A Formação Sete Lagoas em sua área-tipo: fácies, estratigrafia e sistemas deposicionais. Revista Brasileira de Geociências 37 (4-supplement), 1-14.

Vieira, L.C., Trindade, R.I.F., Nogueira, A.C.R., Ader, M., 2007b. Identification of a Sturtian cap carbonate in the Neoproterozoic Sete Lagoas carbonate platform, Bambuí Group, Brazil. Comptes Rendus-Geoscience 339 (3-4), 240-258.

Vilela, F.T., 2010. Caracterização de metadiamictitos ferruginosos da Formação Nova Aurora (Grupo Macaúbas, Orógeno Araçuaí) a oeste de Salinas, MG. Unpublished Master's Thesis. Instituto de Geociências, Universidade Federal de Minas Gerais, Belo Horizonte, Brazil.

Viveiros, J.F.M., Walde, D., 1976. Geologia da Serra do Cabral, Minas Gerais, Brasil. Münsterische Forschungshefte Geologie und Palaeontologie 38 (39), 15-27.

Viveiros, J.F.M., Sá, E.L., Vilela, O.V., Santos, O.M., Moreira, J.M.P., Holder-Neto, F., Vieira, V.S., 1979. Geologia dos vales dos rios Peixe Bravo e Alto Vacaria, norte de Minas Gerais. Boletim do Núcleo Minas Gerais-Sociedade Brasileira de Geologia 1, 75-87.

Williams, I.S., 1998. U-Th-Pb geochronology by ion microprobe. In: McKibben, M.A Shanks, W.C., Ridley, W.I. (Eds.), Applications of microanalytical techniques to understanding mineralizing processes. Reviews in Economic Geology, 7, pp. 1-35.

Zalán, P.V., Romeiro-Silva, P.C., 2007. Proposta de mudança significativa na coluna estratigráfica da Bacia do São Francisco. Simpósio de Geologia de Minas Gerais, 14. Resumos, Diamantina, MG, Brazil, p. 79. 